\title{
31. MAESTRICHTIAN PLANKTONIC FORAMINIFER BIOSTRATIGRAPHY OF THE MAUD RISE (WEDDELL SEA, ANTARCTICA): ODP LEG 113 HOLES 689B AND 690C 1
}

\author{
Brian T. Huber ${ }^{2}$
}

\begin{abstract}
The southernmost record of Maestrichtian pelagic carbonate sedimentation was recovered from ODP Leg 113 Holes $689 \mathrm{~B}$ and $690 \mathrm{C}$, drilled on the Maud Rise in the eastern Weddell Sea sector of the Southern Ocean $\left(65^{\circ} \mathrm{S}\right)$. Well preserved and abundant planktonic foraminifers occur throughout Maestrichtian cores from both holes, providing a nearly complete biogeographic and biostratigraphic history of this region. Diversity is low compared to tropical and subtropical assemblages, with a maximum within sample diversity of 16 planktonic foraminifer species and a diversity total for the Maestrichtian of 24 species. The assemblages are dominated throughout by Heterohelix, Globigerinelloides, and a new species of Archaeoglobigerina, whereas keeled taxa are completely absent from the lower Maestrichtian and rare in the middle through upper Maestrichtian sediments.

Three planktonic foraminifer species are described as new and are recognized as being endemic to the Austral Province. These include Archaeoglobigerina australis $\mathrm{n}$. $\mathrm{sp}$., Hedbergella sliteri $\mathrm{n}$. sp., and Archaeoglobigerina mateola $\mathrm{n}$. sp. The former two species were previously illustrated in reports on Late Cretaceous foraminifers from the Falkland Plateau and the northern Antarctic Peninsula. Two keeled and five non-keeled planktonic foraminifers, previously not found in high latitude Maestrichtian sediments, first appeared at the Maud Rise during the late early and late Maestrichtian. Correlation with their stratigraphic ranges in low latitude sequences shows that their first appearance datums are considerably younger at the Maud Rise than in the lower latitudes. The most likely explanation for this observation is that there was a warming in the south polar region during the late early and late Maestrichtian and a concomitant poleward migration of stenothermal taxa. However, oxygen isotopic paleotemperature results from Sites 689 and 690 (Barrera and Huber, this volume) show a long-term cooling trend throughout the Maestrichtian, indicating that other factors may have played a more important role than temperature in the distribution of Maestrichtian planktonic foraminifers.

A new biostratigraphic scheme is proposed for the Antarctic because of the absence of thermophilic planktonic foraminifers used to identify existing low to middle latitude zones. The Globigerinelloides impensus Partial Range Zone is defined for the late Campanian-Maestrichtian, the Globotruncanella havanensis Partial Range Zone is redefined for the early to late early Maestrichtian, and the Abathomphalus mayaroensis Total Range Zone is recognized. Good quality magnetic polarity data obtained from both Maud Rise sites (Hamilton, this volume) enables magnetobiostratigraphic correlation of twelve foraminifer datums with the geomagnetic polarity time scale of Haq et al. (1987). The geochronology thus obtained is crucial for accurate cross-latitudinal correlation and interpretation of the paleoceanographic history of the Antarctic region during the Maestrichtian time period.
\end{abstract}

\section{INTRODUCTION}

Maestrichtian foraminifers were recovered from Holes 689B $\left(64^{\circ} 31^{\prime} \mathrm{S}, 03^{\circ} 06^{\prime} \mathrm{E}\right)$ and $690 \mathrm{C}\left(65^{\circ} 10^{\prime} \mathrm{S}, 1^{\circ} 12^{\prime} \mathrm{E}\right)$ on the Maud Rise (southern South Atlantic Ocean) during Ocean Drilling Program Leg 113 (Fig. 1). These are the southernmost Maestrichtian assemblages yet recovered from deep sea sediments, providing valuable information for high southern latitude paleobiogeographic and paleoceanographic reconstructions. In addition, the Maud Rise sequence fills an important stratigraphic gap in the southern South Atlantic region because upper Maestrichtian sediments were not recovered at DSDP Sites 327 and 511 on the Falkland Plateau $\left(51^{\circ} \mathrm{S}\right)$, which were the southernmost Cretaceous deep sea sites prior to Leg 113. The nearest other occurrence of Late Cretaceous foraminifers in the high southern latitudes is in ODP Leg 114 Holes 698A and 700B on the northeast Georgia Rise $\left(52^{\circ} \mathrm{S}\right)$ and the James Ross Island region $\left(64^{\circ} \mathrm{S}\right)$ in the northern Antarctic Peninsula (Fig. 1). The faunal distributions at the Leg 114 sites closely correlate with those reported in this study, and are discussed by Huber (in

\footnotetext{
${ }^{1}$ Barker, P. F., Kennett, J. P. et al., 1990. Proc. ODP, Sci. Results, 113: College Station, TX (Ocean Drilling Program).

2 Department of Paleobiology, U.S. Museum of Natural History, Smithsonian Institution, Washington, D.C. 20560
}

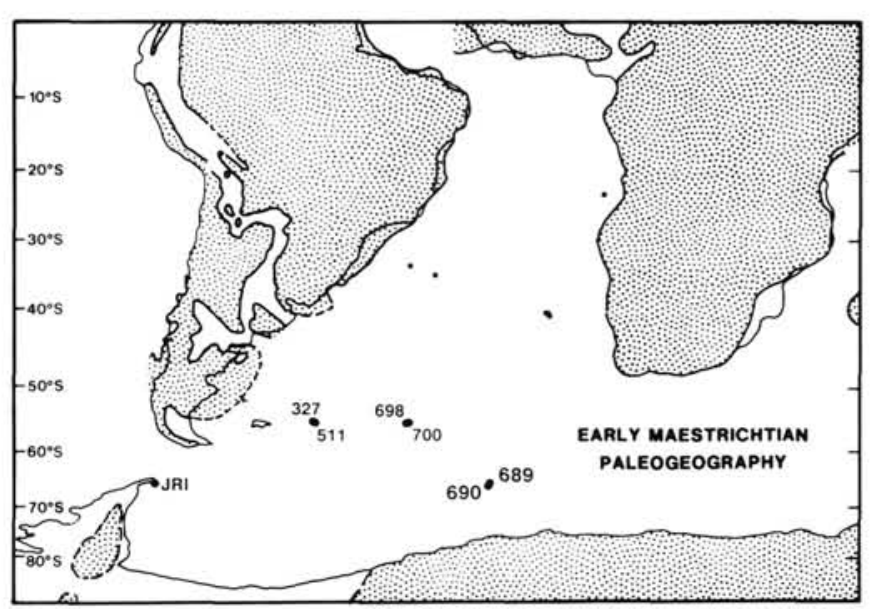

Figure 1. Paleogeographic reconstruction for the early Maestrichtian (after Barron, 1987) showing the regional setting of ODP Sites 689 and 690 (Maud Rise), ODP Sites 698 and 700 (northeast Georgia Rise) and DSDP Sites 327, 511 (Falkland Plateau). JRI refers to the James Ross Island region of Antarctic Peninsula. Small dots represent other South Atlantic deep sea sites yielding Cretaceous sediments. Shaded pattern represents land areas above sea level. The inferred land-sea reconstruction for Antarctica is from Huber (1988b). 
press). The James Ross Island region assemblages, however, were probably influenced by nearshore depositional processes and, thus, they are not considered useful for extra-basinal correlation (Huber, 1988a).

Uncertainties in cross-latitudinal correlation have inhibited previous efforts to accurately portray high southern latitude paleoceanic and paleoclimatic evolution during the Late Cretaceous. Factors that have caused poor biostratigraphic accuracy in this region include: (1) absence of thermophilic planktonic foraminifers used in low latitude zonations, (2) low species diversity and equitability, with dominance by long-ranging, eurytopic taxa, (3) paleoenvironmental influence on faunal distributions, causing diachronous first and last occurrences of some species, (4) provincialism and morphologic variability of several planktonic species, causing uncertainties in phyletic relationships and taxonomic concepts, and (5) limited stratigraphic and areal distribution of circumpolar sites yielding Cretaceous sediments. In spite of these difficulties, several key marker species, previously not found in the south polar regions, occur at the Maud Rise. By correlating the Maud Rise foraminifers with calcareous nannoplankton distributions (Pospichal and Wise, this volume, chapter 30 ) and the geomagnetic reversal stratigraphy Hamilton, this volume), a more precise chronostratigraphic framework can be developed for high southern latitude sequences deposited during the Maestrichtian time period. Thus, the paleoceanographic and paleoclimatic history of this region can be reconstructed more accurately than has hitherto been possible.

\section{METHOD OF STUDY}

Core-catcher samples and one sample per core section were obtained from the Cretaceous sequences recovered at Holes 689B and $690 \mathrm{C}$. These were disaggregated in warm water, ultrasonically cleaned, and sieved through a $63 \mu \mathrm{m}$ screen. The dried residues were sieved through a $150 \mu \mathrm{m}$ screen and relative species abundances for 300 specimens were counted in both the $>150$ $\mu \mathrm{m}$ and $<150 \mu \mathrm{m}$ fractions of each sample (Tables 1-4). Foraminifers occurred in sufficient abundance for complete counts of all samples studied. Benthic foraminifer percentages and species relative abundances were calculated from the count totals.

Relative abundance rankings are as follows: abundant, $26 \%$ $100 \%$; common, $16 \%-25 \%$; few, $6 \%-15 \%$; rare, $2 \%-5 \%$; and very rare, $<1 \%$. Species that were questionably present in samples were not included in counts of species diversity.

Preservation of the Cretaceous foraminifers ranges from moderate to excellent. Specimens distinguished as having moderate preservation are fragmented and strongly etched or overgrown with secondary calcite. Samples showing good preservation yield mostly whole foraminifer tests showing minor evidence of dissolution or secondary calcite overgrowth. Foraminifers whose preservation was judged as excellent show no evidence of diagenetic alteration in transmitted light and their test walls are optically translucent.

Core sample notation follows the standard ODP format, listing the leg number, hole designation, core number and coring method, section number, and the centimeter interval within the section.

\section{FORAMINIFER BIOSTRATIGRAPHY}

\section{Hole 689B}

A $63.9 \mathrm{~m}$ thick sequence of Maestrichtian chalk was recovered from Hole 689B, situated at the crest of the Maud Rise $2,080 \mathrm{~m}$ below sea level in the southeastern South Atlantic Ocean (Fig. 1). The uppermost $2.9 \mathrm{~m}$ of the sequence, from $233.4 \mathrm{me}-$ ters below sea floor (mbsf) to $236.3 \mathrm{mbsf}$, are included in lithologic Subunit IIIA (Fig. 2), which is composed of moderately bioturbated, white nannofossil and foraminifer ooze with some finely dispersed ash interbeds. The remainder of the Maestrichtian sequence comprises lithologic Subunit IIIB. This portion is more indurated than Subunit IIIA and is composed of moderately to strongly bioturbated, white to grey nannofossil chalk and foraminifer nannofossil chalk. Thin chert beds dispersed throughout Subunit IIIB caused poor drilling recovery $(33 \%)$ and eventual abandonment of this hole. The Cretaceous-Tertiary boundary interval was recovered between 84 and $85 \mathrm{~cm}$ in Section 113-689B-25X-5. Details of the foraminiferal turnover through this interval are discussed elsewhere in this volume (see Stott and Kennett, this volume, chapter 47; Thomas, this volume).

The Cretaceous samples at Hole 689B all yield abundant foraminifers whose preservation ranges from excellent, predominantly in the middle of the section, to good in all but the lowermost sample, which was rated as moderately preserved (Fig. 2). Benthic foraminifer percentages are lowest at the base of the sequence (33\% in Sample 113-689B-33X, CC), and range between $3 \%$ and $25 \%$ above that level. Total planktonic species diversity is low throughout the studied interval compared with coeval assemblages from lower latitudes, with fewer than 11 species in the lower Maestrichtian sediments, and up to 16 species in the upper Maestrichtian (Fig. 2).

Assemblages throughout the sequence are dominated by Globigerinelloides multispinatus, Heterohelix spp., and a new species designated as Archaeoglobigerina australis (Fig. 3; Tables 1, 2). Globigerinelloides impensus, which was previously known only from upper Campanian sediments at the Falkland Plateau (Sliter, 1977; Krasheninnikov and Basov, 1983), comprises a significant proportion of the assemblages in the lowermost part of the sequence. This species was not present above Section 113689B-32X-1. Hedbergella holmdelensis occurs only in Sample 113-689C-33X, CC, whereas Hedbergella monmouthensis is present in nearly all Maestrichtian samples in Hole 689B. A distinctive new species, Archaeoglobigerina mateola, also ranges throughout the sequence, occurring in very rare to common abundance. Specimens of Globotruncanella havanensis and the new species Hedbergella sliteri both appear in Section 113-698B$30 \mathrm{X}-1$ and range through Core 113-689B-27X. The Maestrichtian species Globotruncanella petaloidea and Globigerinelloides subcarinatus first occur in upper Maestrichtian Samples 113689B-28X-3, 83-87 cm and $-28 \mathrm{X}-1,76-80 \mathrm{~cm}$, respectively, and Globotruncanella citae and Pseudotextularia elegans first occur in Sample 113-689B-25X-5, 105-107 cm, just below the Cretaceous/Tertiary boundary.

The most pronounced assemblage change in this section occurs in the late early Maestrichtian with the appearance of the double keeled planktonic species Rugotruncana circumnodifer in Sample 113-689B-29X-2, 83-87 cm (267.5 mbsf) and first occurrences of Globotruncana bulloides and G. subcircumnodifer in Sample 113-689B-28X, CC (265 mbsf). The diversity of double keeled taxa increases with the appearance of the late Maestrichtian marker species Abathomphalus intermedius and $A$. mayaroensis (Fig. 2; Table 1).

\section{Hole 690C}

Hole $690 \mathrm{C}$ is located on the southwestern flank of the Maud Rise, $116 \mathrm{~km}$ southwest of Site 689 (Fig. 1) in 2,914 m water depth. Cores 113-690C-16X through $-22 \mathrm{X}$ penetrated $69.2 \mathrm{~m}$ of Maestrichtian chalk that differs from sediments recovered at Hole 689B by its higher terrigenous component of fine-grained quartz, clay, and mica. Drilling recovery averaged $66 \%$ for this sequence. The Cretaceous/Tertiary boundary was determined to occur between 48 and $50 \mathrm{~cm}$ in Section 113-690C-15X-4 and is discussed elsewhere (Pospichal and Wise, this volume, chapter 32; Stott and Kennett, this volume,. chapter 47; Thomas, this volume). 


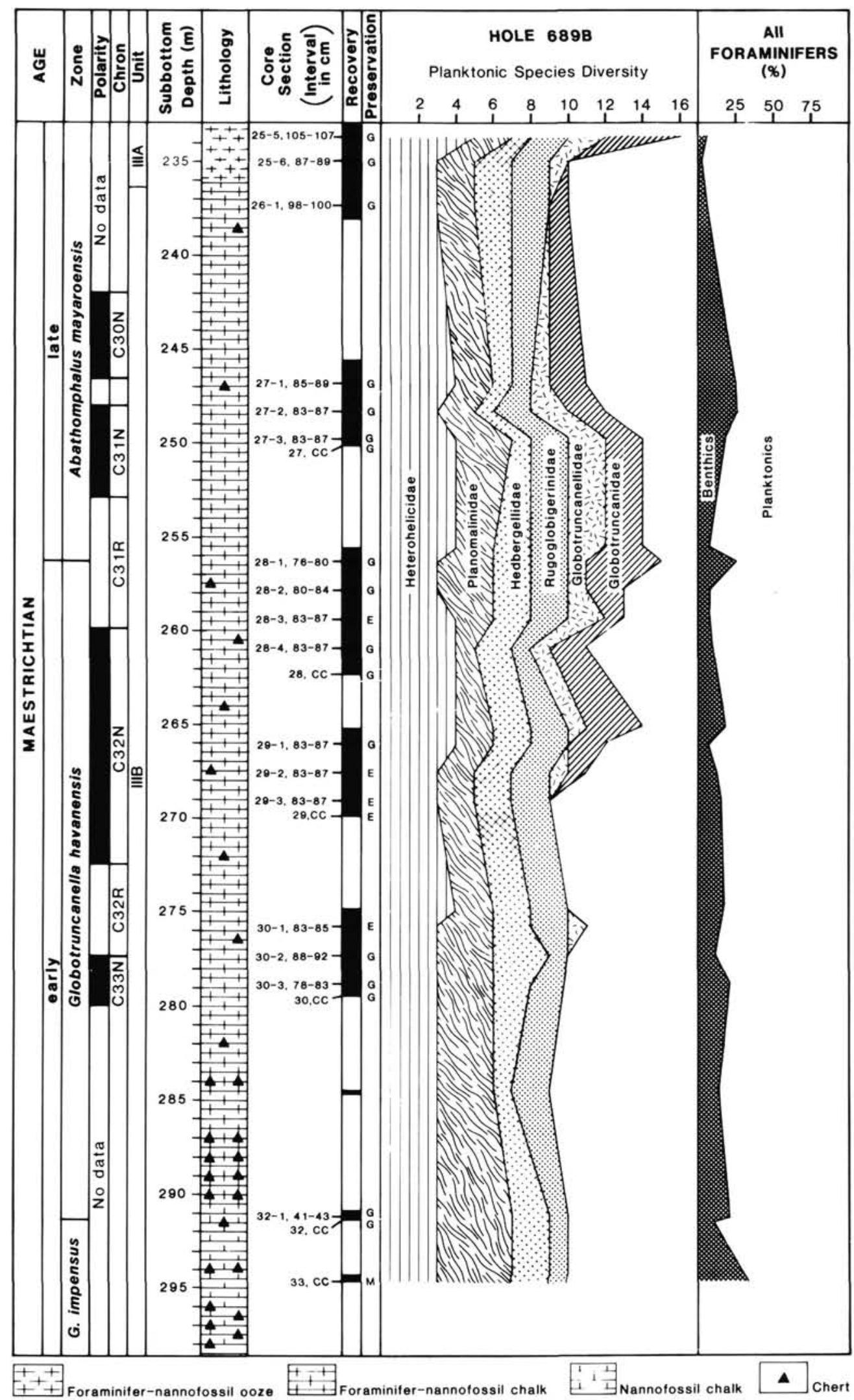

Figure 2. Summary of the drilling recovery, lithology, planktonic/benthic ratios, and planktonic foraminifer species diversity graphs for samples analyzed from the Cretaceous sequence of Hole 689B. These were taxonomically differentiated by family using the classification of Loeblich and Tappan (1988). 


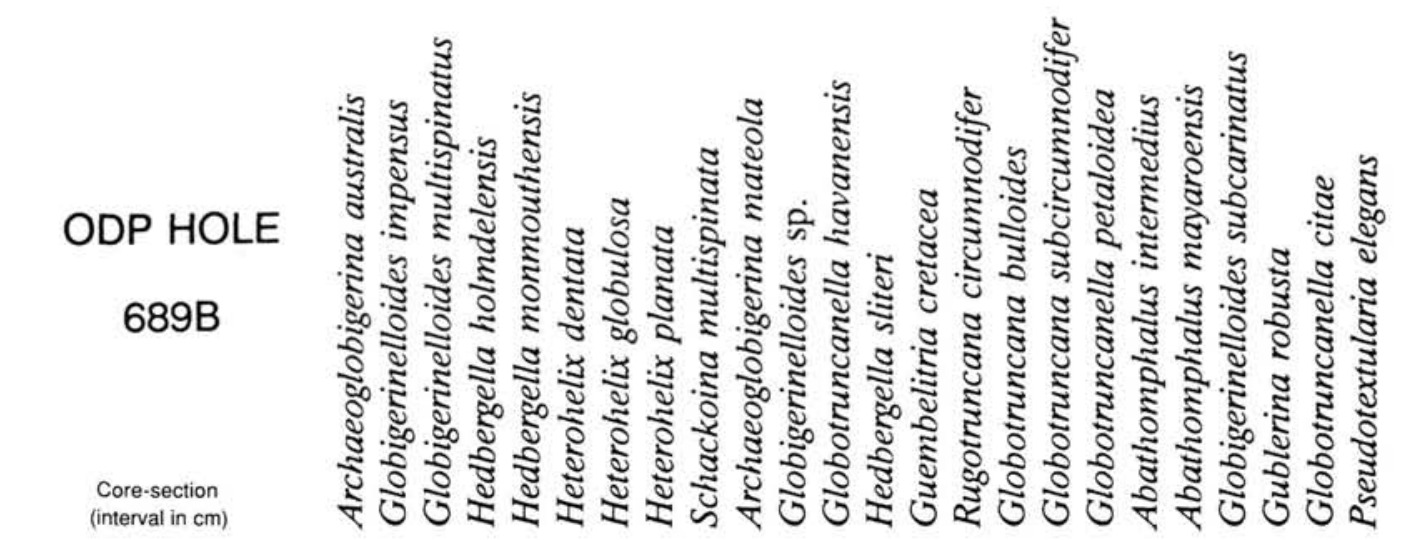

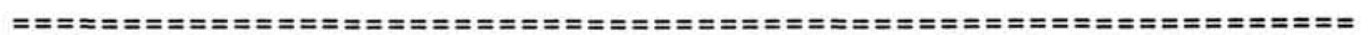

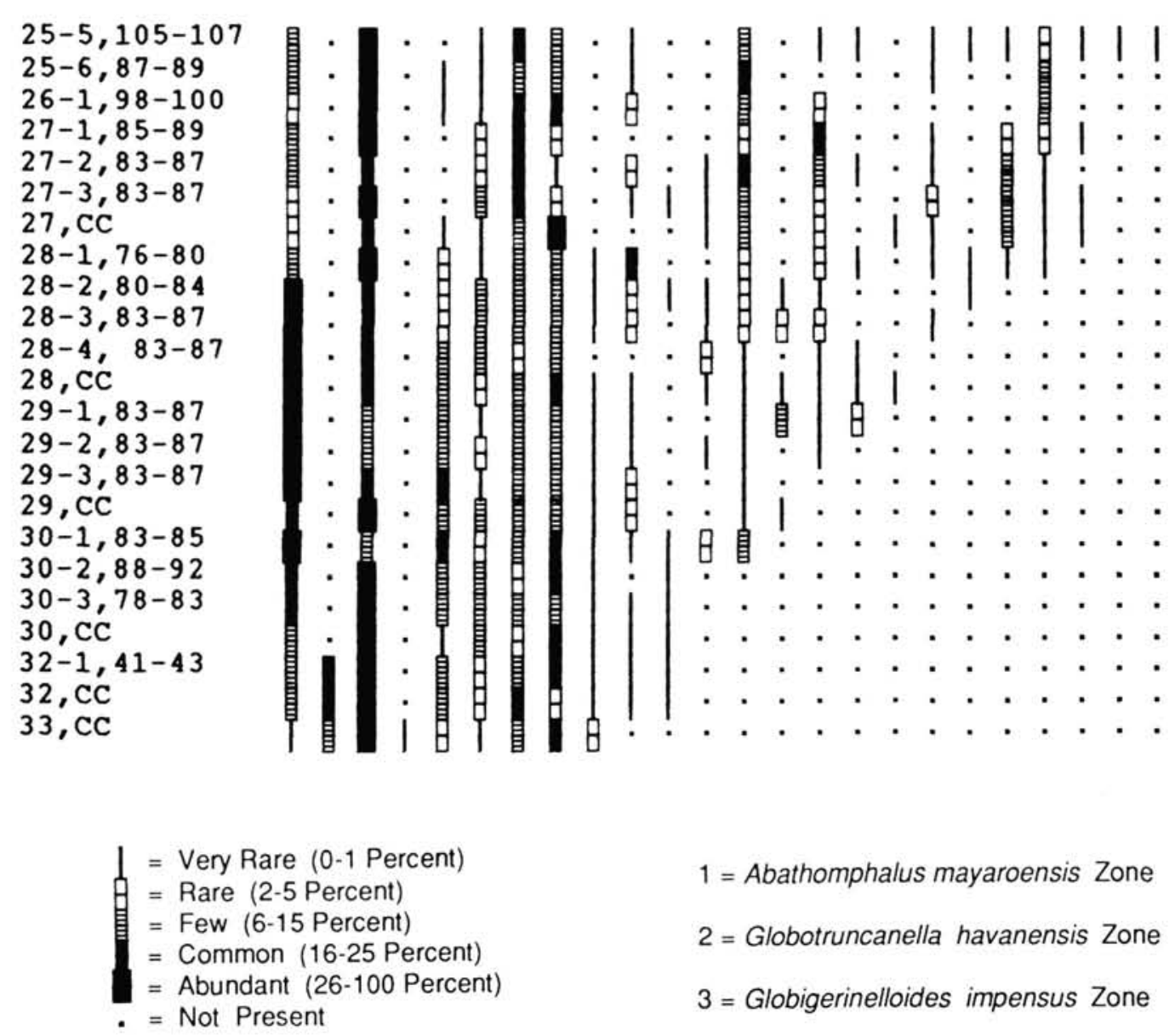

Figure 3. Distribution and relative abundance of Maestrichtian planktonic foraminifers from Hole 689B. The plots are based on combined totals for 300 specimen counts of the $>150 \mu \mathrm{m}$ and $<150 \mu \mathrm{m}$ size fractions (Tables 1,2). Relative abundance rankings and planktonic foraminifer zones are shown at the bottom of the figure. Magnetostratigraphic information from Hamilton (this volume).

Two lithologic units are shown differentiated in the Cretaceous sequence based on the relative amounts of nannofossil and terrigenous components (Fig. 4). Subunit IVC (252.5-281.1 mbsf) contains a lesser amount of terrigenous material than the underlying sequence. It includes white to pale brown, laminated to strongly bioturbated, foraminifer-bearing muddy nannofossil chalk and muddy nannofossil chalk. Unit V (281.1-317 mbsf) includes light gray to pale brown muddy chalk, calcareous mudstone, and nannofossil-bearing mudstone showing minor to mod- erate bioturbation. Chert beds and an ash horizon occur in Core 113-690C-22X. A sharp contact between Unit V and basaltic basement rock occurs at 317 mbsf in Section 113-690C$22 \mathrm{X}, \mathrm{CC}$.

As expected from the close proximity of Sites 689 and 690 , the foraminifer distribution patterns at Hole $690 \mathrm{C}$ are very similar to those of Hole 689B. Foraminifer preservation is excellent in Unit V between Samples 113-690C-19X-2, 119-123 cm and $-21 \mathrm{X}, \mathrm{CC}$ (284-310 mbsf), where clay content is high. Preserva- 
Table 1. Counts of planktonic foraminifers from the $>150 \mu \mathrm{m}$ size fraction for all samples studied at Hole 689B. Crosses denote specimens found after the first 300 specimen count.

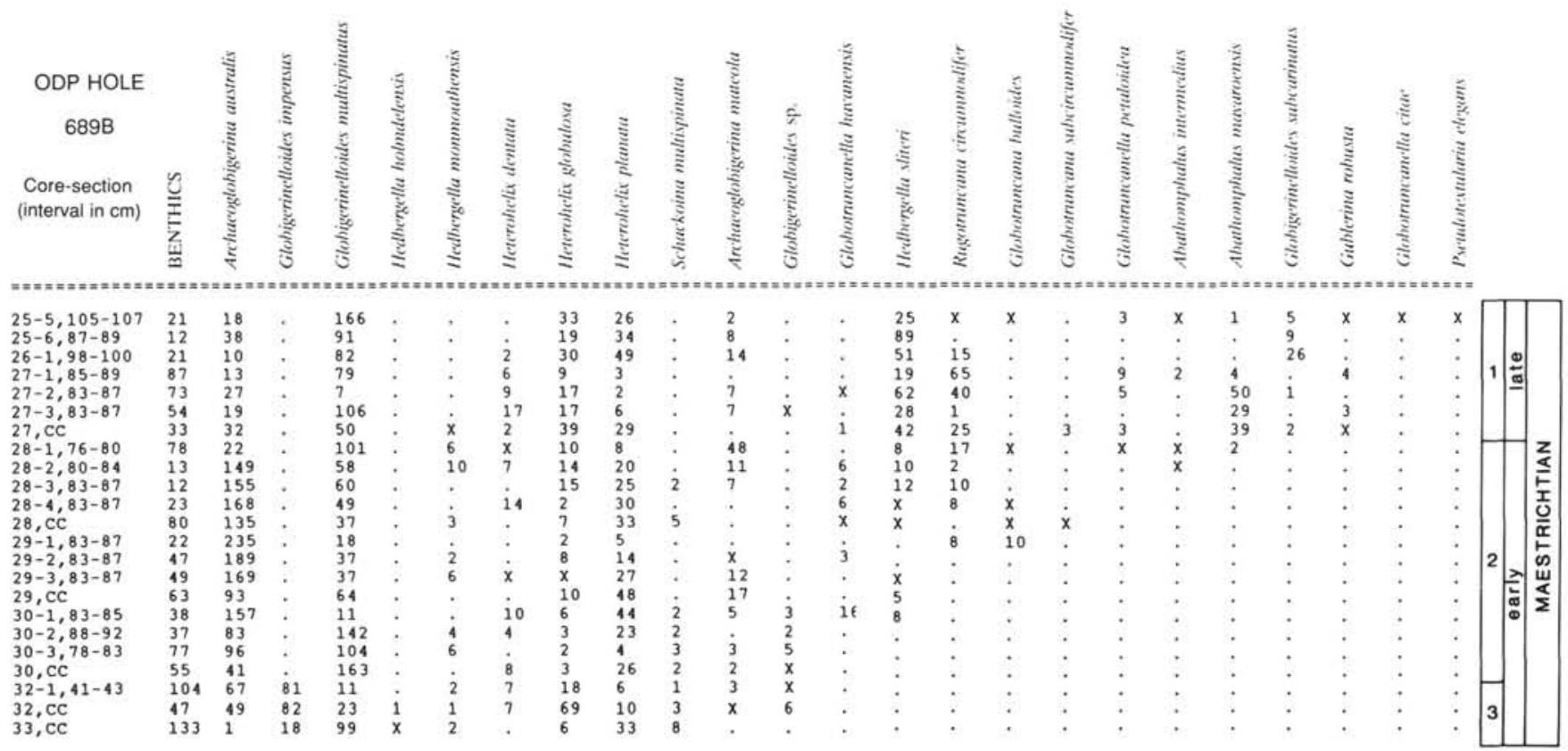

Table 2. Counts of planktonic foraminifers from the $<150 \mu \mathrm{m}$ size fraction for all samples studied at Hole 689B. Crosses denote specimens found after the first 300 specimen count.

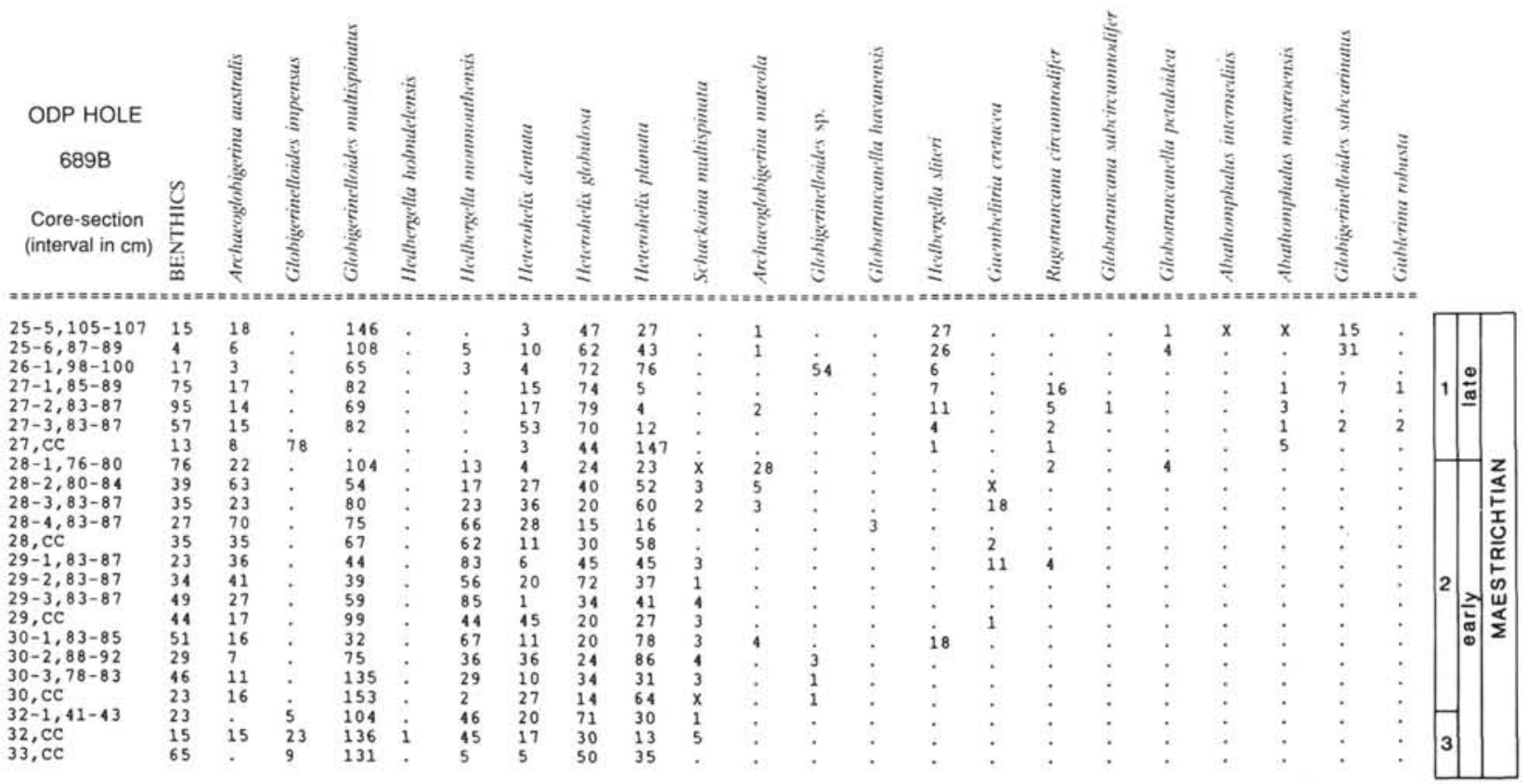

tion is good in all other samples examined (Fig. 4). Benthic foraminifer percentages are lower than for Hole 689B, with highest values $(22 \%)$ just above basaltic basement. Benthic foraminifers are less common in the overlying Cretaceous sequence, comprising less than $6 \%$ of the total assemblage. Total planktonic diversity is less than 12 species for most of the sequence and reaches a maximum of 16 species in Sample 113-690C-19X-1, 119-123 cm (Fig. 4). Diversity remains relatively high throughout the upper Maestrichtian sequence.

The dominant planktonic foraminifers at Hole $690 \mathrm{C}$ are the same species that occur most frequently in the Cretaceous sequence of Hole 689B (Fig. 5; Tables 3, 4). Archaeoglobigerina australis is common to abundant in nearly all samples up to the upper Abathomphalus mayaroensis Zone. Archaeoglobigerina 


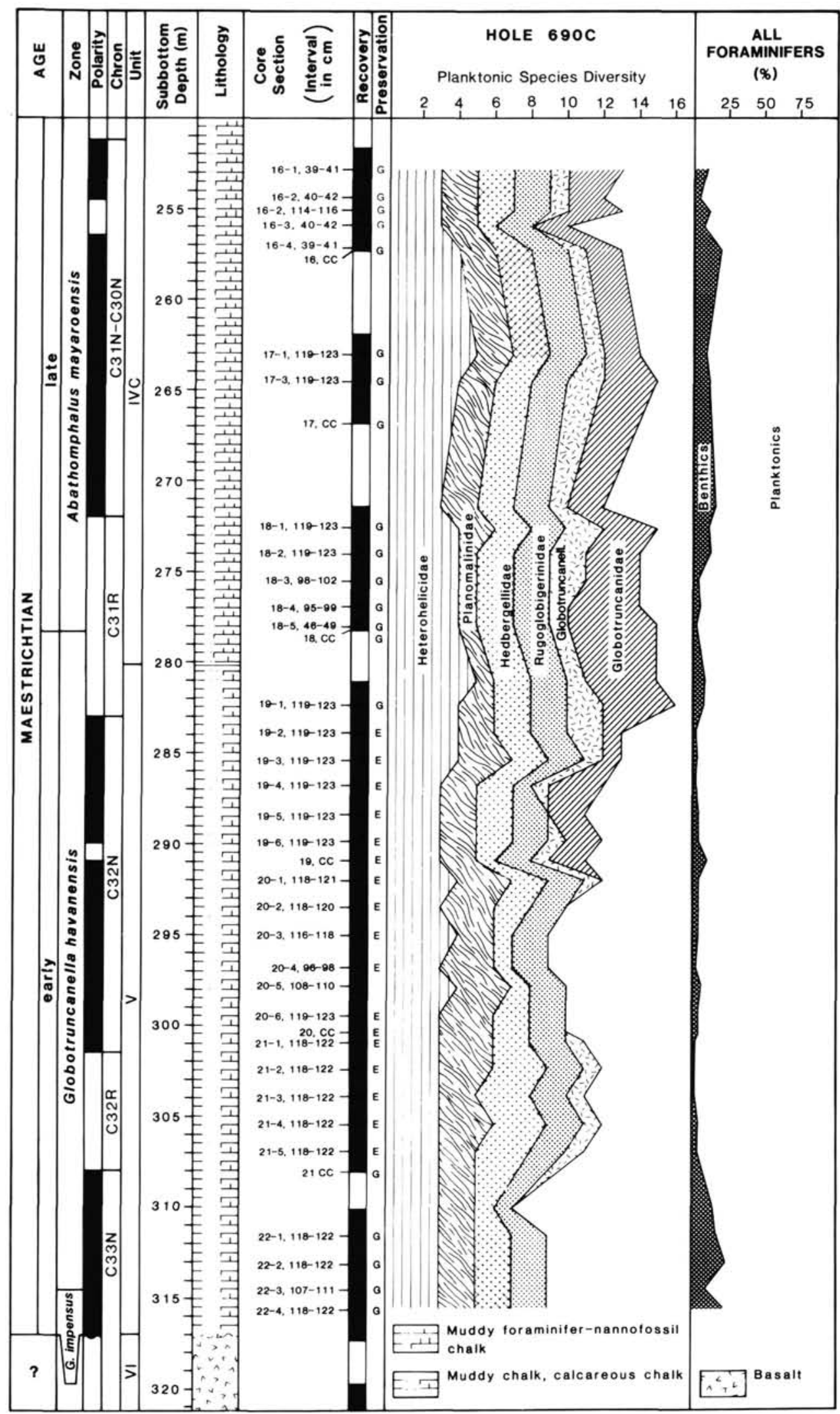

Figure 4. Summary of the drilling recovery, lithology, planktonic/benthic ratios, and planktonic foraminifer species diversity graphs for samples analyzed from the Cretaceous sequence of Hole 690C. These were taxonomically differentiated by family using the classification of Loeblich and Tappan (1988). 
mateola also ranges throughout most of the Maestrichtian sequence at Hole $690 \mathrm{C}$, occurring as a minor component of the planktonic assemblages. Specimens of Globigerinelloides impensus occur only at the bottom of Hole $690 \mathrm{C}$ (314 mbsf to 316 mbsf), as at Hole 689B. Both Globotruncanella havanensis and Hedbergella sliteri first occur in lower Maestrichtian Sample 113-690C-21X-5, 118-122 cm and have a sporadic distribution above. The latter species is consistently present at higher abundances within the upper Maestrichtian sediments. Globotruncanella petaloidea and Globigerinelloides subcarinatus first ap- pear in Samples 113-690C-19X-4, 119-123 cm and -17X, CC, respectively, and Globotruncanella citae first occurs in Sample 113-690C-16X-2, 114-116 cm and ranges to just below the Cretaceous/Tertiary boundary (Fig. 5; Tables 3, 4; Stott and Kennett, this volume, chapter 47).

A conspicuous influx of double keeled planktonic foraminifers and increase in species diversity also occurs in the late early Maestrichtian sequence at Hole 690 C, beginning in Sample 113690C-19X, CC (Fig. 5; Table 3). Specimens of Rugotruncana circumnodifer and Globotruncana subcircumnodifer are both

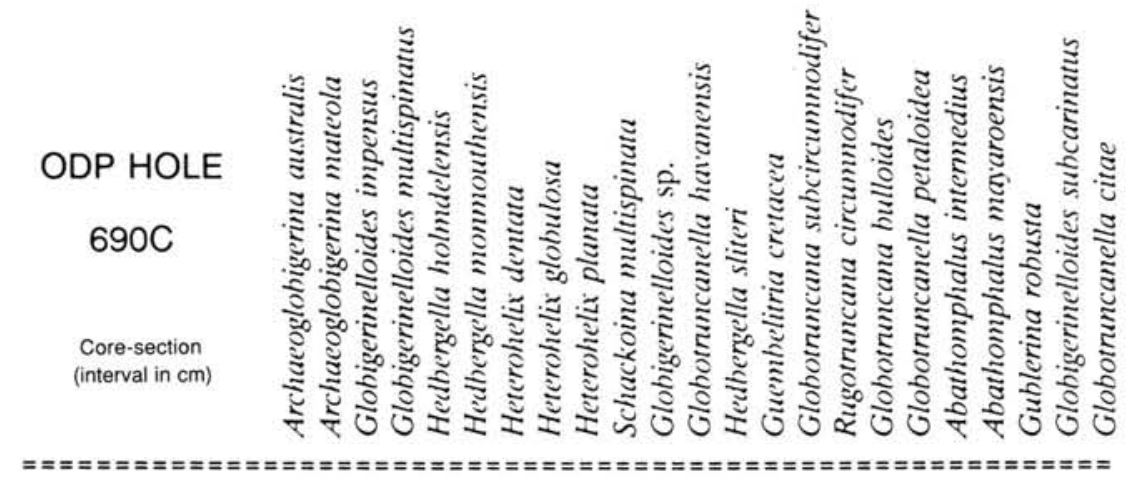

$$
\begin{aligned}
& 16-1,39-41 \\
& 16-2,40-42 \\
& 16-2,114-116 \\
& 16-3,40-42 \\
& 16-4,39-41 \\
& 16, C C \\
& 17-1,119-123 \\
& 17-3,119-123 \\
& 17, C C \\
& 18-1,119-123 \\
& 18-2,99-103 \\
& 18-3,98-102 \\
& 18-4,95-99 \\
& 18-5,46-49 \\
& 18, C C \\
& 19-1,119-123 \\
& 19-2,119-123 \\
& 19-3,119-123 \\
& 19-4,119-123 \\
& 19-5,110-112 \\
& 19-6,119-121 \\
& 19, C C \\
& 20-1,118-121 \\
& 20-2,118-120 \\
& 20-3,116-118 \\
& 20-4,96-98 \\
& 20-5,108-110 \\
& 20-6,119-123 \\
& 20, C C \\
& 21-1,118-122 \\
& 21-2,118-122 \\
& 21-3,118-122 \\
& 21-4,118-122 \\
& 21-5,118-122 \\
& 21, C C \\
& 22-1,118-122 \\
& 22-2,118-122 \\
& 22-3,107-111 \\
& 22-4,118-122 \\
& \\
& 19
\end{aligned}
$$
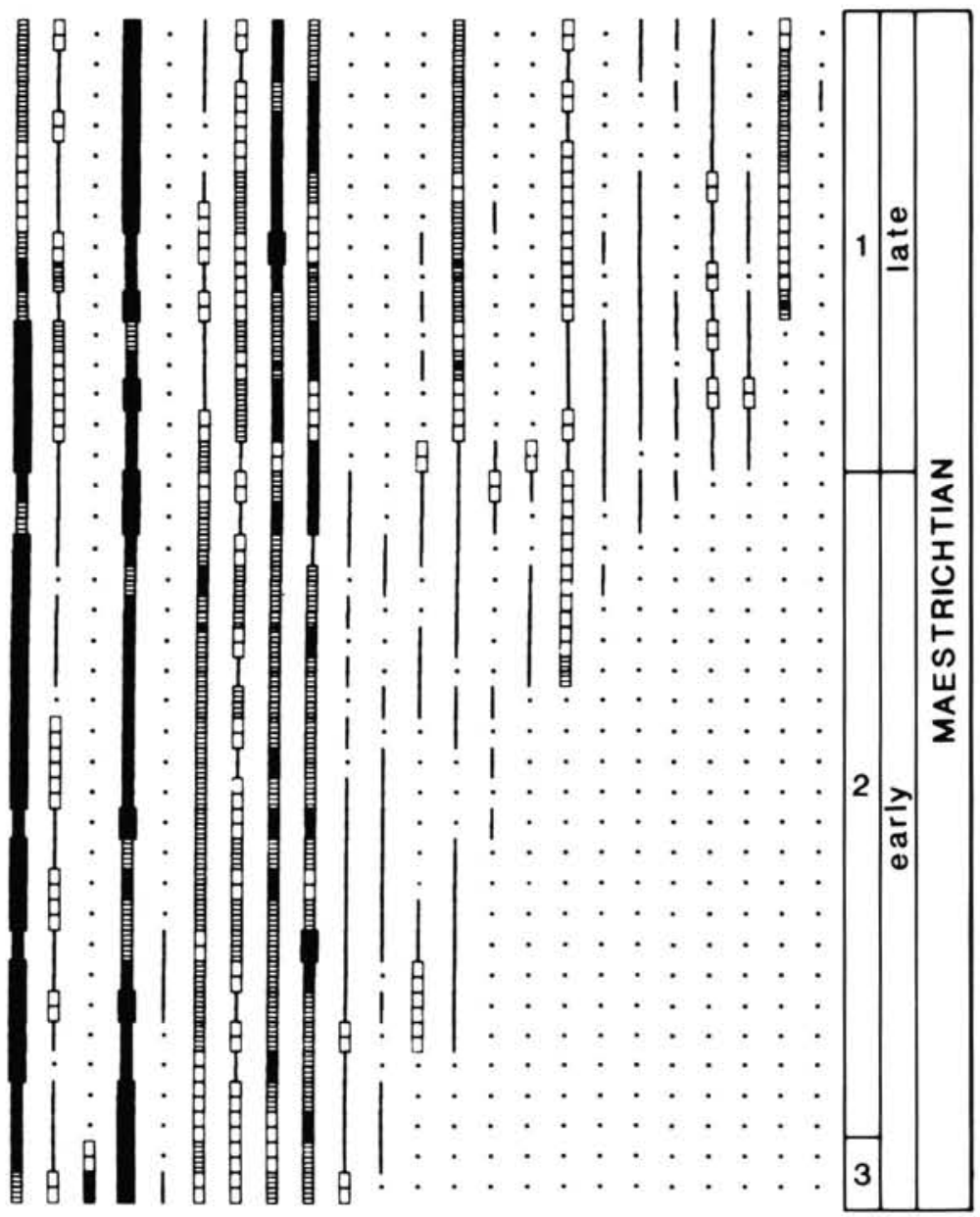

Figure 5. Distribution and relative abundance of Maestrichtian planktonic foraminifers at Hole 690C. The plots are based on combined totals for 300 specimen counts of the $>150 \mu \mathrm{m}$ and $<150 \mu \mathrm{m}$ size fractions (Tables 3, 4). Magnetostratigraphic information from Hamilton (this volume). See Figure 3 for the key to relative abundance rankings and planktonic foraminifer zonal subdivisions. 
Table 3. Counts of planktonic foraminifers from the $>150 \mu \mathrm{m}$ size fraction for all samples studied at Hole $690 \mathrm{C}$. Crosses denote specimens found after the first 300 specimen count.

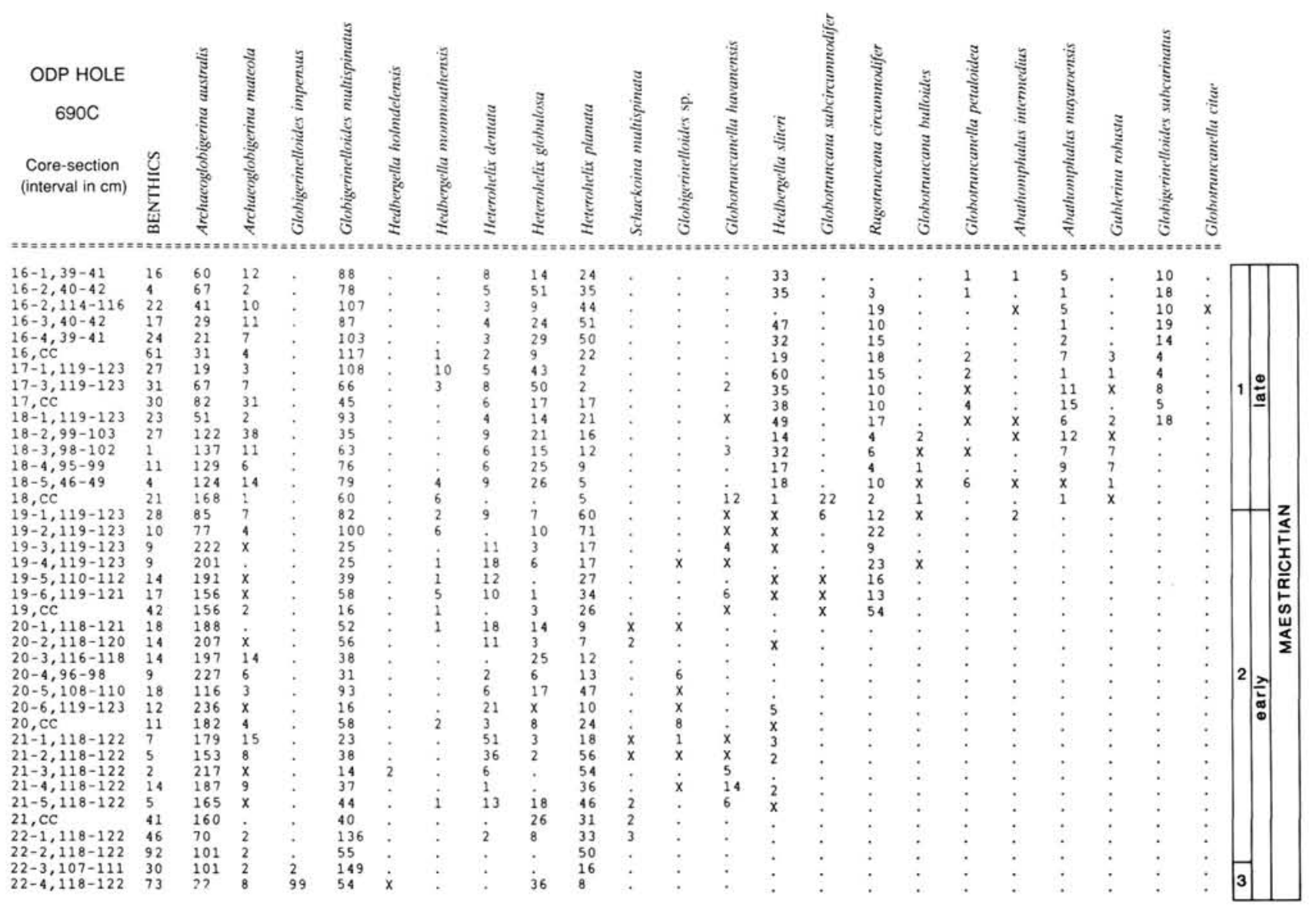

present in this sample. This is followed by first appearances of Globotruncana bulloides in Section 113-690C-19X-4, Abathomphalus intermedius in Section 113-690C-19X-1, and A. mayaroensis in Section 113-690C-18X-5.

\section{BIOSTRATIGRAPHIC ZONATION}

Previous studies of Late Cretaceous planktonic foraminifer assemblages from the southern South Atlantic region were unable to apply low latitude biostratigraphic schemes because of the absence of zonal marker species (Sliter, 1977; Krasheninnikov and Basov, 1983, 1986; Huber, 1988a). Uncertainty in crosslatitudinal biostratigraphic correlation is especially prevalent in the lower Maestrichtian sediments at the Maud Rise; the zonal marker species Globotruncana falsostuarti, $G$. ventricosa, and $G$. gansseri are completely absent and the assemblages are dominated by long-ranging, eurythermal taxa. Previous zonal schemes proposed for Upper Cretaceous high latitude sequences in New Zealand (Webb, 1971) and the Antarctic Peninsula (Huber, 1988a), shown in Figure 6, are of limited regional utility because of incomplete stratigraphic reference sections or local facies control on faunal distributions. Incomplete recovery of Maestrichtian sediments at DSDP Sites 327 and 511 on the Falkland Plateau (Figs. 1, 7) limited the biostratigraphic utility of the planktonic foraminifers described by Sliter (1977) and Krashenninikov and Basov (1983). Thus, Maud Rise Sites 689 and 690 provide the most complete biostratigraphic range data for Maestrichtian planktonic foraminifers yet recovered from the high southern latitudes. Description of a new Antarctic zonal scheme is presented below.
Globigerinelloides impensus Partial Range Zone

Definition. Interval from the first to last occurrence of G. impensus Sliter.

Associated species. Globigerinelloides multispinatus, Hedbergella holmdelensis, and Archaeoglobigerina australis.

Age. Late Campanian to early Maestrichtian. The LAD of G. impensus is in upper Chron 33N (early Maestrichtian) at Sites 689 and 690, and is estimated at $73.71 \mathrm{Ma}$ (Table 5).

Distribution. From Samples 113-689B-33X, CC through -32X-1, 41$31 \mathrm{~cm}(294.3-291.2 \mathrm{mbsf})$ and 113-690C-22X-4, 118-122 $\mathrm{cm}$ through $-22 X-3,107-111 \mathrm{~cm}(315.6-314.5 \mathrm{mbsf})$. The earliest occurrence of Globigerinelloides impensus at Holes 689B and 690 C are in the lowermost samples analyzed and, therefore, the total stratigraphic range of this species was probably not recovered. Sliter (1977) reported that this species was restricted to upper Campanian sediments at Falkland Plateau DSDP Site 327, occurring only in Core 36-327A-13R. This latter core is separated from overlying Maestrichtian sediments by a $23 \mathrm{~m}$ coring gap (Fig. 7). Although Krasheninnikov and Basov (1983) reported G. impensus to range from Cores 71-511-26R to -23R at Falkland Plateau DSDP Site 511 (Fig. 1), re-examination of samples from that sequence suggests that this species is absent from the Maestrichtian core. This species was probably mistaken for a similar form, presently referred to as Globigerinelloides $\mathrm{sp}$., which occurs in low abundance in Core 71-511-23R. Therefore, the last appearance datum (LAD) of $G$. impensus at Site 511 is shown in Figure 7 at the top of Core 71-511-24R, which was assigned to the late Campanian by Wind and Wise (1983). The $G$. impensus Zone was not recovered at DSDP Site 208 (Tasman Sea), as coring terminated in middle Maestrichtian sediments only $10 \mathrm{~m}$ below the Abathomphalus mayaroensis Zone. Absence of G. impensus from the Lopez de Bertodano Formation in the James Ross Island region (Antarctic Peninsula) (Huber, 1988a) may be due to paleobathymetric exclusion of this species or because that sequence is younger than was previously reported. 
Table 4. Counts of planktonic foraminifers from the $<\mathbf{1 5 0} \mu \mathrm{m}$ size fraction for all samples studied at Hole $690 \mathrm{C}$. Crosses denote specimens found after the first 300 specimen count.

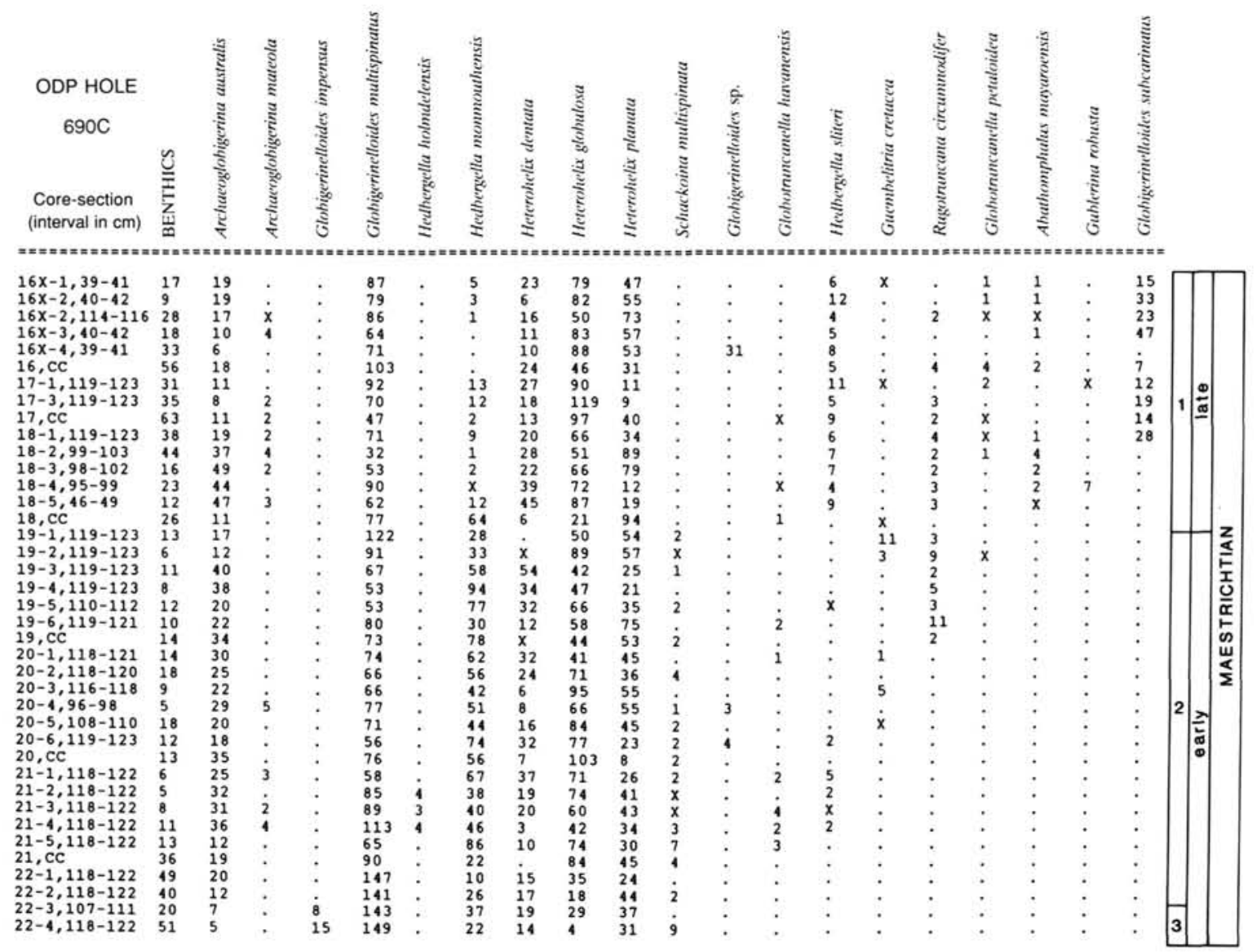

\section{Globotruncanella havanensis Interval Zone}

Definition. Interval from the last occurrence of Globigerinelloides impensus to the first appearance of Abathomphalus mayaroensis.

Age. Early Maestrichtian. This zone extends from upper Chron 33N to the middle of Chron $31 R$ at Sites 689 and 690.

Associated species. Hedbergella monmouthensis, H. sliteri, Globotruncanella havanensis, Archaeoglobigerina australis, A. mateola, and Rugotruncana circumnodifer.

Distribution. The range of the nominate species at the Maud Rise [Samples 113-689B-30X, CC through -28X-2, 80-84 cm (284.5-267.5 mbsf); -690C-22X-2, 118-122 cm through -18X, CC (313.1-281.1 mbsf)] does not extend to the bottom of this zone. Globotruncanella havanensis was found in Cores 10,11, and 12 at Site 327 (Fig. 7), which were considered as early Maestrichtian by Wind and Wise (1983). A single specimen of $G$. havanensis was reported by Huber (1988a) from lower Maestrichtian sediments on Seymour Island (Antarctic Peninsula). This species was not reported at Site 511 (Krashenninikov and Basov, 1983) or at Site 208 (Webb, 1973b). The lower boundary of the G. havanensis Zone was originally defined by Douglas (1969) by the last occurrence of Globotruncanita calcarata and its upper boundary was defined by the first occurrence of Globotruncana aegyptiaca. Both keeled species are absent from Austral Province assemblages.

\section{Abathomphalus mayaroensis Total Range Zone}

Definition. Brönnimann (1952) originally defined this zone on the total range of $A$. mayaroensis.

Associated species. Gublerina robusta, Globigerinelloides subcarinatus, Hedbergella sliteri, Globotruncanella petaloidea, Rugotruncana circumnodifer, and Abathomphalus intermedius.

Age. Late Maestrichtian. The first appearance datums (FAD's) of Abathomphalus mayaroensis and the calcareous nannoplankton species
Nephrolithus frequens occur within $0.5 \mathrm{~m}$ of each other at Sites 689 and 690 and are used as the basis for delimiting the early/late Maestrichtian boundary at both sites. First occurrences of both species in Chron 31R at Sites 689 and 690 , about $69.9 \mathrm{Ma}$ (Table 5), are earlier than their FAD's in Chron 30N reported from lower latitude sequences (Premoli Silva, 1977; Kent and Gradstein, 1985; Monechi and Thierstein, 1985) and, thus, their distributions are considered as time transgressive from the high to low latitudes (see below).

Distribution. From Samples 113-689B-28X-1, 76-80 cm through $-25 X-5,88-90 \mathrm{~cm}(256.3-233.7 \mathrm{mbsf})$ and $-690 \mathrm{C}-18 \mathrm{X}-5,46-49 \mathrm{~cm}$ through $-15 X-4,45-47 \mathrm{~cm}$ (277.9-247.8 mbsf). The late Maestrichtian A. mayaroensis Zone was not recovered at either DSDP Site 327 or 511 at the Falkland Plateau (Fig. 7). At DSDP Site 208, Webb (1973b) reported the FAD of $A$. mayaroensis in Section 21-208-33-2, $4.5 \mathrm{~m}$ below the top of the Cretaceous sediments. This species was probably absent from Maestrichtian sediments on Seymour Island because of the shallow paleodepth (Huber, 1988a).

\section{BIOCHRONOLOGY}

Sedimentation rate curves for Holes 689B and 690C, shown plotted on Figure 8, are based on the stratigraphic positions of magnetostratigraphic chron boundaries (Hamilton, this volume) and their correlation with the Haq et al. (1987) time scale for the Maestrichtian. This time scale was chosen because of the absence of definite Campanian age calcareous nannoplankton that have not been reworked (Pospichal and Wise, this volume, chapter 30), but presence of a relatively long interval of normal polarity assigned to Chron $33 \mathrm{~N}$ at the bottom of Holes $689 \mathrm{~B}$ and $690 \mathrm{C}$. Figure 8 shows that the Maestrichtian rate of sedimentation at Hole 689B was slower (about $5.18 \mathrm{~m} / \mathrm{m} . \mathrm{y}$.) and 


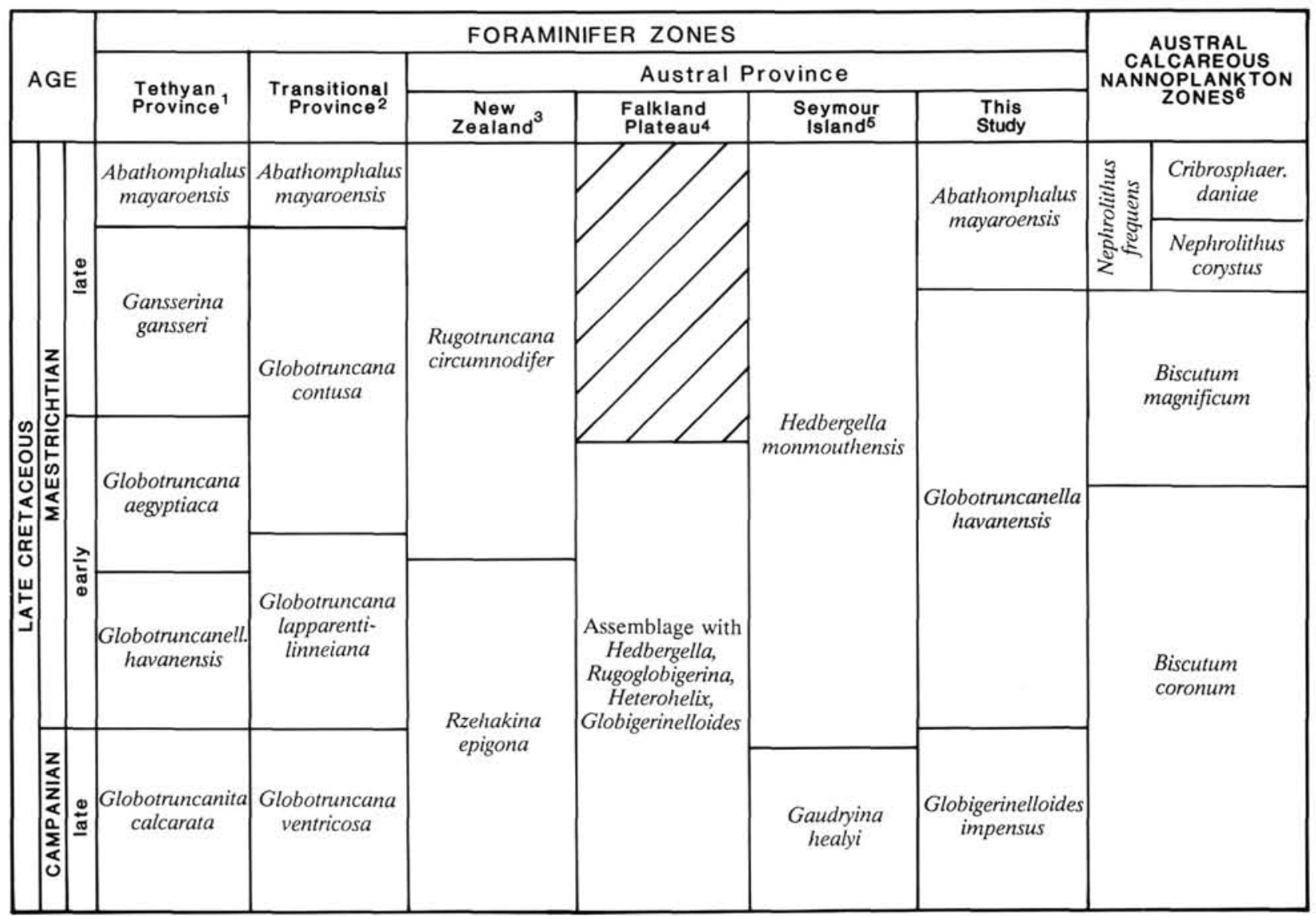

Figure 6. Comparison of zonal schemes developed for the planktonic foraminifer Tethyan and Transitional Provinces of the Southern Hemisphere with the scheme proposed in this study and the calcareous nannoplankton zonation of Wind and Wise (1983) for the Austral Province. ${ }^{1}$ Caron, $1985 ;{ }^{2}$ Wright and Apthorpe, $1976 ;{ }^{3} \mathrm{Webb}, 1971 ;{ }^{4} \mathrm{Krasheninnikov}$ and Basov, $1986 ;{ }^{5} \mathrm{Huber}, 1988 ;{ }^{6} \mathrm{Wind}$ and Wise, 1983.

Table 5. Depths and ages assigned to the planktonic foraminifer datums shown in Figure 8.

\begin{tabular}{|c|c|c|c|c|c|}
\hline \multirow[b]{2}{*}{ SPECIES } & \multirow[b]{2}{*}{ DATUM } & \multicolumn{2}{|c|}{ HOLE 689B } & \multicolumn{2}{|c|}{ HOLE $690 \mathrm{C}$} \\
\hline & & $\begin{array}{l}\text { DEPTH } \\
\text { (mbsf) }\end{array}$ & $\begin{array}{l}A C E \\
(\mathrm{Ma})\end{array}$ & $\begin{array}{l}\text { DEPTH } \\
\text { (mbsf) }\end{array}$ & $\begin{array}{c}\text { ACE } \\
(\mathrm{Ma})\end{array}$ \\
\hline $\begin{array}{l}\text { Pseudotextularia elegans } \\
\text { Globotruncanella citae } \\
\text { Globigerinelloides subcarinatus } \\
\text { Abathomphalus mayaroensis } \\
\text { Schackoina multispinatus } \\
\text { Globotruncanella petaloidea } \\
\text { Globotruncana subcircumnodifer } \\
\text { Globotruncana bulloides } \\
\text { Rugotruncana circumnodifer } \\
\text { Hedbergella sliteri } \\
\text { Globtruncanella havanensis } \\
\text { Globigerinelloides impensus }\end{array}$ & $\begin{array}{l}\text { FAD } \\
\text { FAD } \\
\text { FAD } \\
\text { FAD } \\
\text { LAD } \\
\text { FAD } \\
\text { FAD } \\
\text { FAD } \\
\text { FAD } \\
\text { FAD } \\
\text { FAD } \\
\text { LAD }\end{array}$ & $\begin{array}{l}233.66 \\
233.66 \\
256.36 \\
256.36 \\
256.36 \\
259.43 \\
259.43 \\
266.03 \\
267.53 \\
275.73 \\
275.73 \\
291.21\end{array}$ & $\begin{array}{l}66.51 \\
66.51 \\
69.86 \\
69.86 \\
69.86 \\
70.43 \\
70.43 \\
71.32 \\
71.50 \\
72.64 \\
72.64 \\
74.72\end{array}$ & $\begin{array}{l}255.14 \\
272.59 \\
278.30 \\
282.29 \\
283.79 \\
290.60 \\
290.60 \\
290.60 \\
306.92 \\
306.92 \\
314.50\end{array}$ & $\begin{array}{l}67.22 \\
69.34 \\
69.92 \\
70.40 \\
70.43 \\
71.05 \\
71.05 \\
71.05 \\
72.70 \\
72.70 \\
73.71\end{array}$ \\
\hline
\end{tabular}

more constant than at Hole $690 \mathrm{C}$, which has an average sedimentation rate of $9.53 \mathrm{~m} / \mathrm{m}$.y. Extrapolation of these sedimentation rate curves to the bottom of both holes indicates that the oldest sediments recovered from Hole 689B were deposited during the latest Campanian, at about $75.05 \mathrm{Ma}$, and the oldest at Hole $690 \mathrm{C}$ were deposited during the earliest Maestrichtian at about $73.96 \mathrm{Ma}$.

Age estimates for 12 planktonic foraminifer datums, listed in Table 5 and shown on Figure 8, were determined by plotting the stratigraphic level of their first or last appearance on (or extrapolated beyond) the sedimentation rate curves for both Maud
Rise sites. Between the two sites, agreement of these age estimates is dependent on completeness of recovery and sample spacing. For example, the LAD of Globigerinelloides impensus is older at Hole 689B (74.72 Ma) than at Hole 690 C (73.71 Ma) because of a $20 \mathrm{~m}$ recovery gap between Cores 113-689B-30X and $-32 X$ (Fig. 2). Although age assignments for datums that occur within intervals of good recovery compare to within 0.6 m.y. of each other at the two Maud Rise sites, it is difficult to further evaluate their accuracy because of the paucity of paleomagnetically constrained datums elsewhere. The best and closest site for comparison is ODP Hole 700B, drilled on the northeast Georgia Rise in the southern South Atlantic (Fig. 1). The Maestrichtian foraminifers from that site are nearly identical to the Maud Rise assemblage in species composition and the biostratigraphic datums occur within the same magnetic polarity sequences (Huber, in press).

Several species listed in Table 5 have diachronous first occurrences compared to their lower latitude distribution. The FAD at the Maud Rise of Abathomphalus mayaroensis in Chron 31R at the Maud Rise, and at Hole $700 \mathrm{~B}, 13^{\circ}$ of latitude to the north (Huber, in press), is considerably older than its first occurrence within Chron $30 \mathrm{~N}$ in the Umbrian Appenines (Premoli Silva, 1977; Monechi and Thierstein, 1985). Berggren et al. (1983) recorded an FAD of $A$. mayaroensis that is slightly younger than the Leg 113 and 114 sites to the south, occurring just below the C31N/C31R boundary at the Rio Grande Rise in the South Atlantic $\left(35^{\circ} \mathrm{S}\right.$ paleolatitude). These authors also report that the FAD of Globotruncanella havanensis is just below the 


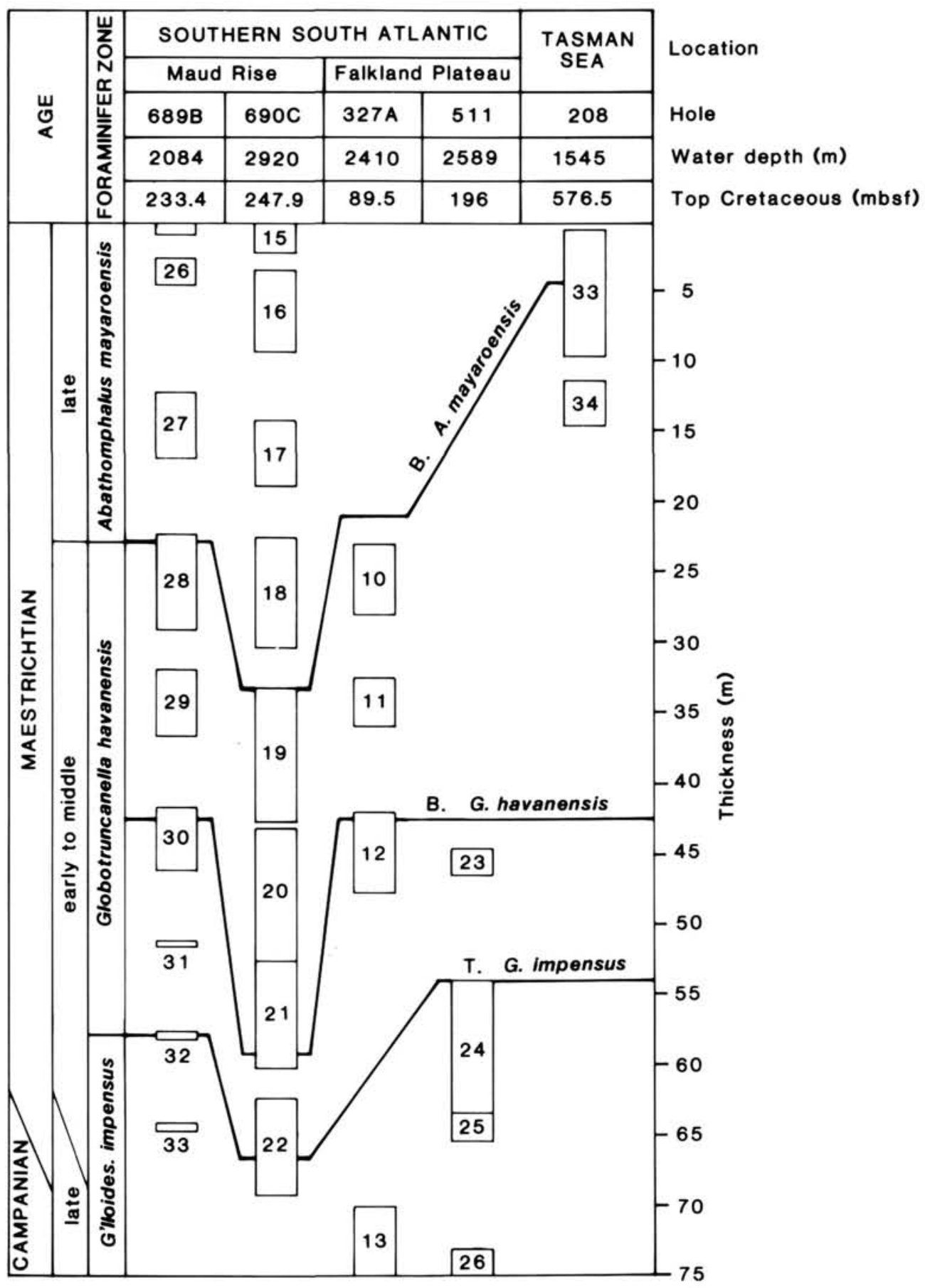

Figure 7. Correlation of southern South Atlantic and Tasman Sea deep sea sites based on the last occurrence (T) of Globigerinelloides impensus, the first occurrence (B) of Globotruncanella havanensis, and the first occurrence (B) of Abathomphalus mayaroensis, or absence of these species. All core-sections (numbered in boxes) are scaled to their stratigraphic thickness and those that have relatively complete Cretaceous-Tertiary boundaries are scaled from the top of the Cretaceous sediments.

C 32N/C32R boundary, whereas this species first occurs at the base of Chron 32R at the Maud Rise. Although Boersma (1984) reported the FAD of $A$. mayaroensis at the base of $\mathrm{C} 31 \mathrm{~N}$ at Hole 525A on the Walvis Ridge, she considered that occurrence to be an artifact of sediment reworking. In the circum-Pacific region, the FAD of $A$. mayaroensis is reported by Sliter (1989) to occur within the middle of Chron $31 \mathrm{~N}$.
Species with older FAD's in the south polar region than in the low latitudes include Pseudotextularia elegans, Globigerinelloides subcarinatus, Globotruncana bulloides, and Globotruncana subcircumnodifer. All of these taxa range from the Campanian through Maestrichtian in tropical and subtropical regions (Caron, 1985; Sliter, 1989), but first occur in upper lower to upper Maestrichtian sediments at the Maud Rise. 


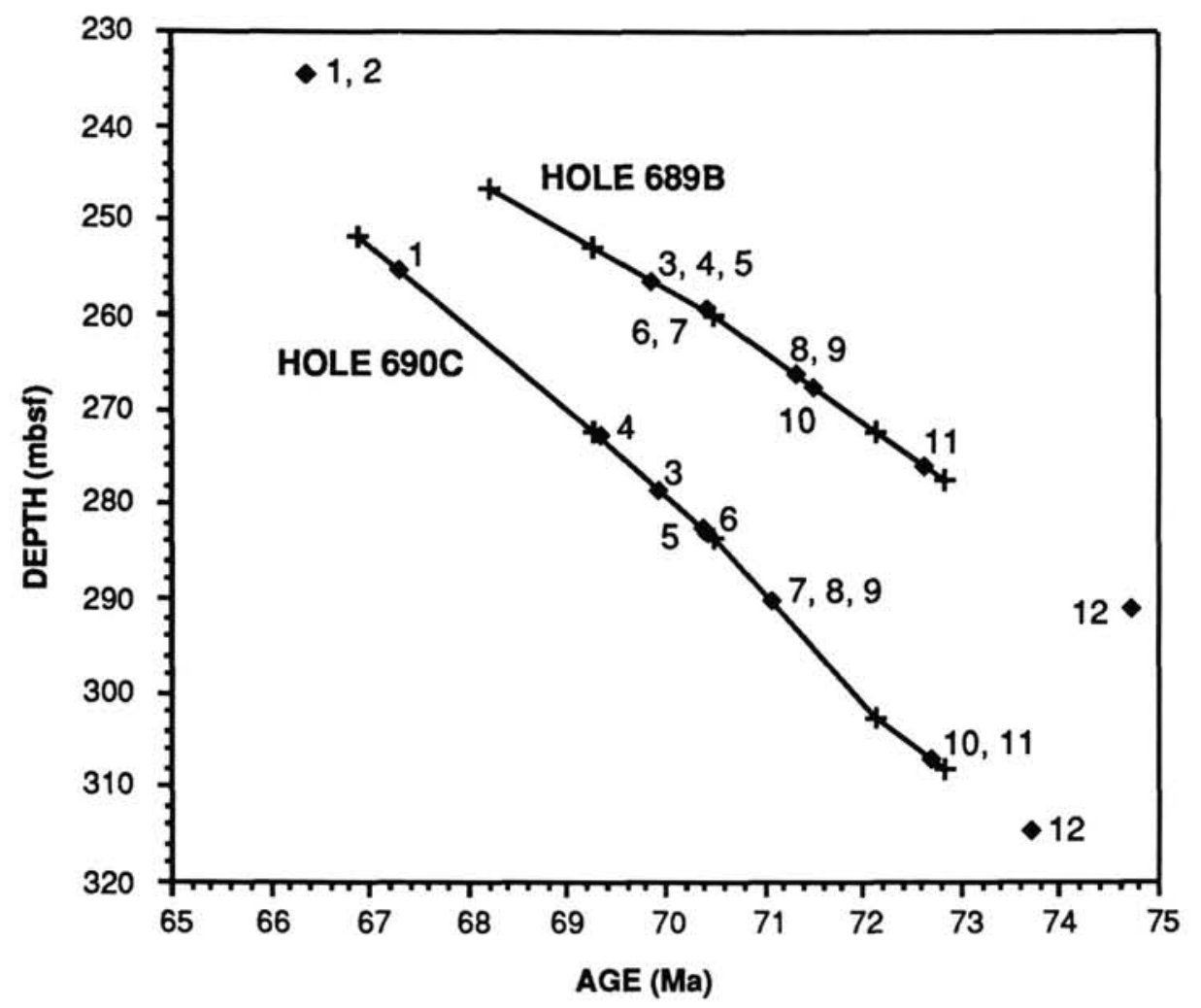

1 FAD G. citae

2 FAD P. elegans

3 FAD A. mayaroensis

4 FAD G. subcarinatus

5 LAD S. multispinatus

6 FAD G. petaloidea

7 FAD G. subcircumnodifer

8 FAD G. havanensis

9 FAD H. sliteri

10 FAD G. bulloides

11 FAD $R$. circumnodifer

12 LAD G. impensus

Figure 8. Maestrichtian biochronology for Maud Rise Holes 689B and 690C. Crosses mark the positions of magnetic polarity reversal boundaries determined by Hamilton (this volume) and diamonds represent planktonic foraminifer datums on the sedimentation rate curve. Age assignments for the chron boundaries are from Haq et al. (1987). See also Table 5.

\section{PALEOBIOGEOGRAPHY}

\section{The Austral Biogeographic Province}

Late Cretaceous planktonic foraminifers from the Maud Rise and other sites that occupied paleolatitudes poleward of about $50^{\circ} \mathrm{S}$ are included in the Austral Province. Scheibnerova (1971, 1973), Sliter (1977), and Krashenninikov and Basov (1983, 1986) distinguished this cool-temperate biogeographic province from the Transitional (subtropical) and Tethyan (tropical) Provinces based on the absence of Late Cretaceous thermophilic planktonic foraminifers. Species of Racemiguembelina, Ventilabrella, Planoglobulina, Hastigerinoides, Sigalia, Pseudogeumbelina, Plummerita, Trinitella, and single keeled Globotruncanita are completely absent from the Austral Province and double keeled globotruncanids are very rare to absent. Prior to this study, no planktonic foraminifer taxa were recognized as having distributions restricted to any of the extra-tropical provinces. Instead, Austral Province assemblages were identified by having low species diversity and dominance of simple globular species of the Heterohelicidae, Planomalinidae, Hedbergellidae, and rare Rugoglobigerinidae (Scheibnerova, 1971; Webb, 1973a; Sliter, 1977; Krasheninnikov and Basov, 1983).

Analysis of Cretaceous foraminifer assemblages from the Maud Rise and Falkland Plateau reveals that several planktonic foraminifer species were restricted in their paleobiogeographic distribution to the high southern latitudes. Globigerinelloides impensus was previously known only from the Falkland Plateau (Sliter, 1977; Krasheninnikov and Basov, 1983), but its occurrence at the Maud Rise extends its paleobiogeographic range to the eastern side of the southern South Atlantic. The new species Archaeoglobigerina australis is not only a dominant component of the Maud Rise assemblages, but it also dominates the late Campanian-early Maestrichtian assemblages at Sites 327 and
511. Considerable morphologic variability of this species (see systematic discussion) has led to substantial confusion in taxonomic concepts of the high latitude morphotypes and incorrect age assignments for the species that were misidentified. Detailed comparison and morphometric study of large populations of $A$. australis from the Falkland Plateau and the Maud Rise (Huber, $1987 ; 1988$ b) has shown that specimens previously referred to as Rugoglobigerina pilula Belford, Rugoglobigerina rotundata Brönnimann, and Hedbergella monmouthensis (Olsson) by several authors (Sliter, 1977; Krasheninnikov and Basov 1983; Huber, 1988a) are in fact morphovariants of Archaeoglobigerina australis. Topotypes of the incorrectly identified taxa were morphometrically compared with $A$. australis and their taxonomic distinction has been documented (Huber, 1988b).

A third species determined to be restricted to the Austral Province is Hedbergella sliteri (previously designated as H. holmdelensis by Sliter, 1977 and $H$. monmouthensis by Webb, 1973b and Huber, 1988a). Morphometric comparison of populations of this species from the Maud Rise and the Falkland Plateau with topotypes of $H$. holmdelensis and $H$. monmouthensis $(\mathrm{Hu}-$ ber, 1988b) has also clarified their taxonomic differences (see also systematic discussion below). The paleobiogeographic range of $H$. sliteri extends from the southern South Atlantic to the southwest Pacific Ocean.

Planktonic specimens similar in morphology to the distinctive new species Archaeoglobigerina mateola were found in one sample from lower Maestrichtian sediments on Seymour Island (northern Antarctic Peninsula) (distinguished as Rugoglobigerina sp. 2 by Huber, 1988a). The absence of $A$. mateola from other austral localities is puzzling. The range of this species at the Maud Rise does overlap with the age of sediments recovered in Cores 10 through 12 of Falkland Plateau Hole 327A (Fig. 7), but examination of samples from these cores has failed to reveal 
its presence. Archaeoglobigerina mateola is quite rare and somewhat sporadic in its occurrence within its Maestrichtian range at the Maud Rise. Thus, its absence from the Falkland Plateau cannot be entirely substantiated until the existing material is studied further or until younger Maestrichtian sediments are recovered.

The northern limit of the Austral Province in the southern South Atlantic probably occurred poleward of about $40^{\circ} \mathrm{S}$ paleolatitude (the Walvis Ridge), but north of $55^{\circ} \mathrm{S}$ paleolatitude (the Falkland Plateau and Leg 114 sites shown on Fig. 1). Assemblages reported from DSDP Sites 524, 525, and 527, drilled on the Walvis Ridge (Boersma, 1984; Smith and Poore, 1984), are considerably more diverse in keeled and total planktonic foraminifer species than sites drilled further south on the Falkland Plateau (Sliter, 1977; Krashenninikov and Basov, 1983), the northeast Georgia Rise (Huber, in press) and the Maud Rise. This biogeographic boundary most likely paralleled the border between two oceanic surface gyres which differed primarily in temperature. These water masses probably converged at about the latitude of the northern Falkland Plateau, as was postulated by Ciesielski et al. (1977).

\section{PALEOENVIRONMENTAL INFERENCES}

The most important factor controlling Cretaceous planktonic foraminifer biogeography has been interpreted to be the arrangement of paleoclimatic belts (Douglas, 1972; Sliter, 1972, 1977; Krasheninnikov and Basov, 1986). On the basis of changes in foraminifer distributions at Falkland Plateau DSDP Sites 327 and 511, Krasheninnikov and Basov (1986) constructed a paleoclimatic curve for the Barremian-Maestrichtian time period, which is partly reproduced in Figure 9. Absence of keeled taxa and dominance of simple globigerine species of Heterohelix, Globigerinelloides, and Hedbergella were used by these authors as indicators of cold conditions, while warm periods were recognized by the presence of higher diversity assemblages yielding keeled "stenothermal" species. Although Krasheninnikov and Basov (1986) show a cooling trend throughout the Maestrichtian period, data for the late early through late Maestrichtian interval of their plot are lacking due to an erosional disconformity on the Falkland Plateau (Wind and Wise, 1983; this study).

If the Krasheninnikov and Basov (1986) method for determining relative paleotemperatures is used to reconstruct the Maestrichtian climate at the Maud Rise, a significantly different paleotemperature curve would result. The increase in planktonic foraminifer species diversity and occurrence of several keeled planktonic species during the late early through late Maestrichtian (Figs. 2, 4, 9) would suggest a warming of high latitude surface waters and a poleward expansion of the Transitional Province. Although this interpretation is consistent with results from middle latitude paleobotanical and plant physiognomy studies in the Northern Hemisphere by Wolfe (1987), which indicate a late Maestrichtian warming event, oxygen isotope values from the Maud Rise (Barrera and Huber, this volume; Fig. 9), the Antarctic Peninsula (Barrera et al., 1987), and the equatorial Pacific Ocean (Douglas and Savin, 1975, Shackleton and Boersma, 1981) show a cooling trend throughout the Maestrichtian. Furthermore, a global cooling was proposed by Pospichal and Wise (this volume, chapter 30) and Worsley and Martini (1970) for the late Maestrichtian to explain the equatorward migration of the calcareous nannoplankton species Nephrolithus frequens. The earlier appearance of Abathomphalus mayaroensis at the Maud Rise relative to lower latitude sites indicates that this species also migrated from the high to low latitudes, perhaps following cooler surface waters as they expanded toward the tropics.

It is apparent from the above discrepancies among paleoclimatic indicators that latitudinal climatic gradients or relative paleotemperature curves cannot be reconstructed by using keeled/ non-keeled ratios of planktonic foraminifers alone. As Cifelli and Scott (1986, p. 66) noted, "...the parallels of latitude are man-made constructs and not, in themselves, natural phenomena." It is well known that many biotic and abiotic parameters affecting modern foraminifer distributions cannot be directly measured from the fossil record. In addition to the arrangement of paleoclimatic belts, the salinity and density stratification of surface waters, surface water turbidity, nutrient supply, and seasonal variation in environmental factors all played important roles in controlling the distribution of planktonic foraminifers. The poleward pulses of planktonic foraminifer migration observed in the upper lower through upper Maestrichtian sediments at the Maud Rise and other southern high latitude sites would be best explained by a concomitant shift in water mass boundaries. However, this is not a satisfactory explanation because of the lack of corroborating evidence from the calcareous nannoplankton distributions (Pospichal and Wise, this volume, chapter 30 ) and oxygen and carbon isotope results (Barrera and Huber, this volume) from both Maud Rise sites. Unfortunately, the present stratigraphic and geographic record from the high southern latitudes is too limited to decipher the paleoceanographic changes that most influenced the anomalous Antarctic foraminifer distributions.

\section{CONCLUSIONS}

1. Sedimentation rates determined for the Maestrichtian sequence at Holes $689 \mathrm{~B}$ and $690 \mathrm{C}$ average $5.18 \mathrm{~m} / \mathrm{m}$.y and 9.53 $\mathrm{m} / \mathrm{m} . \mathrm{y}$, respectively. No depositional hiatuses are apparent at either Maud Rise site.

2. The oldest sediments recovered from Hole 689B were deposited in the latest Campanian, at about $75.05 \mathrm{Ma}$, whereas those of Hole 690C were deposited in the earliest Maestrichtian at about $73.96 \mathrm{Ma}$.

3. Recognition of three new planktonic foraminifer species that were endemic to the circum-Antarctic region during the Maestrichtian time period confirms the existence of the Austral Province as a biogeographically segregated entity. Planktonic foraminifer assemblages within this province are characterized by their low species diversity, paucity or absence of many thermophilic index species found in the Tethyan and Transitional Provinces, and dominance by simple globular planktonic morphotypes. The Maud Rise assemblages are nearly identical to upper Campanian-Maestrichtian planktonic foraminifers described from the Falkland Plateau and other high southern latitude assemblages, but distinctly differ from coeval assemblages from the Walvis Ridge (about $40^{\circ} \mathrm{S}$ paleolatitude) and foraminifer faunas to the north. This biogeographic isolation was probably caused by convergence of subtropical and temperate oceanic gyres at about $50^{\circ} \mathrm{S}$ paleolatitude in the South Atlantic.

4. Several keeled and non-keeled species have considerably younger first occurrences at the Maud Rise than in lower latitude sequences. These poleward migration events are estimated to have occurred at about $71,70.5,69.5$, and $66.5 \mathrm{Ma}$. Although this may be attributed to latitudinal shifts in warm versus cool water mass boundaries, no corroborating evidence has been obtained from analysis of calcareous nannoplankton distributions (Pospichal and Wise, this volume, chapter 30) and oxygen isotope paleotemperatures (Barrera and Huber, this volume). Paleoceanographic factors other than temperature, such as changes in surface water turbidity, nutrient supply, salinity, and/or vertical stratification, must be invoked as causes for the diachronous planktonic foraminifer distributions.

\section{SYSTEMATIC DESCRIPTIONS}

Planktonic foraminifer species encountered in this study are briefly discussed below and are illustrated on Plates 1-6. Synon- 


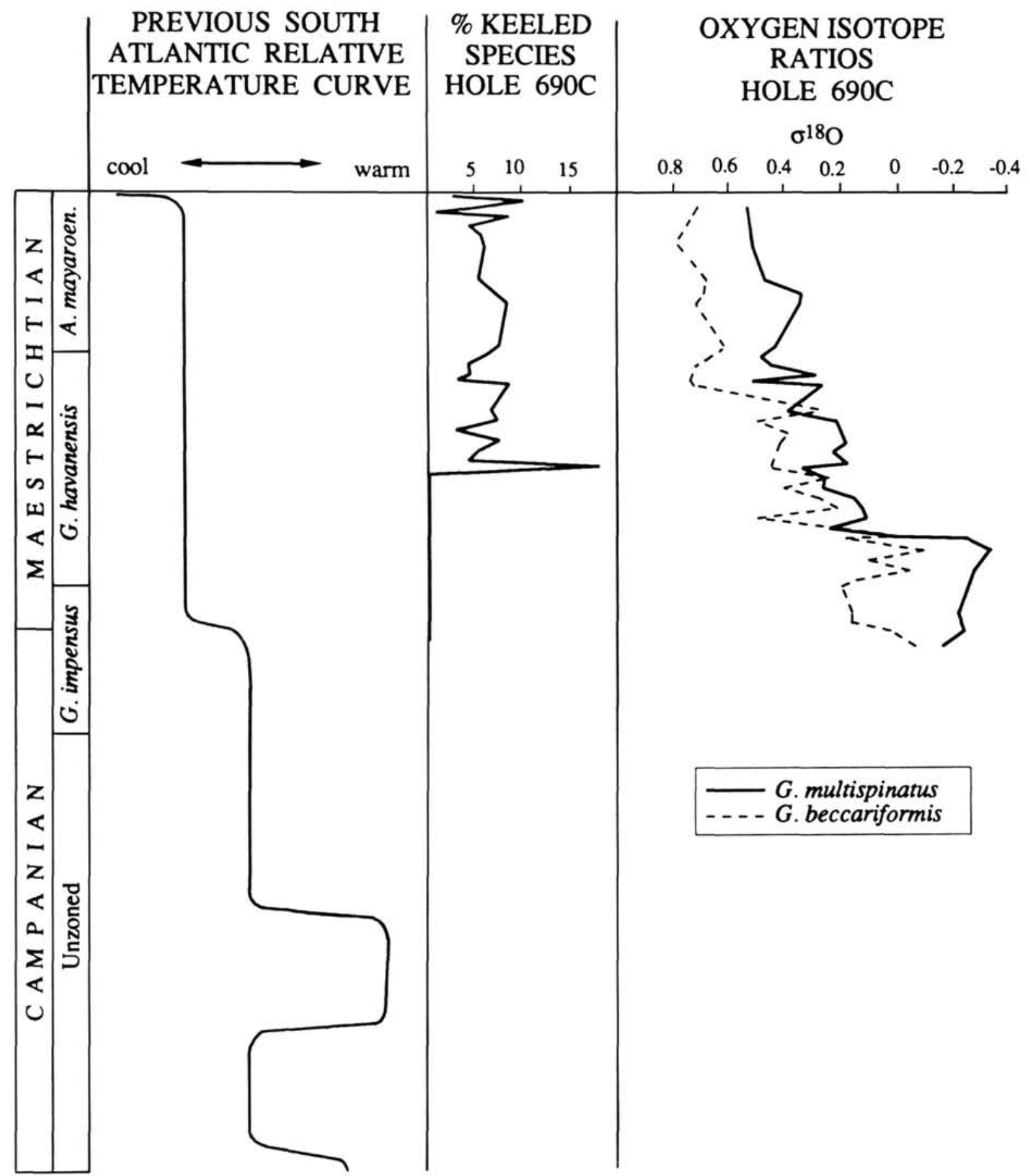

Figure 9. Relative paleotemperature curve for the Campanian-Maestrichtian periods from Krasheninnikov and Basov (1987) compared with results from the Maestrichtian of Hole 690C showing a relative abundance plot for keeled planktonic foraminifers from Hole $690 \mathrm{C}$ (this study) and the oxygen isotope paleotemperature curve from Barrera and Huber (this volume) for Gavelinella beccariformis (a benthic species) and Globigerinelloides multispinatus (a planktonic species).

ymy lists are limited to the original reference, with additional synonymies added for clarification of taxonomic uncertainties among some species. Three species are formally described as new. Details of their morphologic variability, distinction from other taxa, size range, and stratigraphic distribution are also provided. Holotypes and paratypes of each new species are deposited at the U.S. National Museum of Natural History in Washington, D.C. Discussion of some previously described taxa is included to elucidate differences in morphologically similar or phyletically related forms.

\section{Guembelitria cretacea Cushman}

$$
\text { (Pl. 1, Fig. 1) }
$$

Guembelitria cretacea Cushman, 1933, p. 37, pl. 4, figs. 12a-b.

Occurrence. First appears in Samples 113-689B-29X, CC and -690C$21 \mathrm{X}-5,118-122 \mathrm{~cm}$ and sporadically occurs in low abundance through 
the younger Maestrichtian sequence. Caron (1985) and other authors have noted that the range of this species is restricted to the Maestrichtian stage.

\section{Heterohelix dentata Stenestad}

(Pl. 1, Fig. 2)

Heterohelix dentata Stenestad, 1968, p. 67-68, pl. 1, figs. 3-6, 8-9, 11; pl. 2, figs. 1-3.

Heterohelix glabrans (Cushman), Sliter, 1977, p. 547, pl. 7, fig. 1. Huber, 1988 a, p. 206, fig. 27.2-27.3.

Remarks. This species is distinguished from Heterohelix glabrans (Cushman) by having chambers that are more reniform in morphology.

Occurrence. Occurs in all Cretaceous samples at Sites 689 and 690 in very rare to high abundance. Ranges from the upper Campanian through Maestrichtian elsewhere.

\section{Heterohelix globulosa (Ehrenberg)}

(Pl. 1, Figs. 3, 4)

Textularia globulosa Ehrenberg, 1840 (1838), p. 135, pl. 4, figs. 2B, 4B, $5 \mathrm{~B}, 7 \mathrm{~B}, 8 \mathrm{~B}$.

Remarks. Most forms included in this species resemble the specimen shown on Pl. 1, Fig. 3, which has fine costate ornamentation on all chambers. However, some (e.g., Pl. 1, Fig. 4) have an elongate test with pustulose surface ornament on the earlier chambers, resembling Heterohelix papula Belford, which was described from the Santonian Toolonga Calcilutite in Western Australia (Belford, 1960, 1983), but has not since been reported elsewhere.

Occurrence. Present in all Cretaceous samples at Sites 689 and 690 in rare to high abundance. A common component of Late Cretaceous assemblages worldwide.

\section{Heterohelix planata (Cushman)}

(Pl. 1, Figs. 5-6)

Guembelina planata Cushman, 1938, p. 12-13, pl. 2, figs. 13-14.

Heterohelix pulchra (Brotzen), Sliter, 1977, p. 541, pl. 6, figs. 7-9.

Remarks. Compressed forms with apertures bordered by imperforate flanges and bearing faint, discontinuous costae and sometimes thin keels on the early chambers are included in this species.

Occurrence. Occurs throughout the Cretaceous at Sites 689 and 690, in rare to high abundance. Its range elsewhere has been established as Campanian-Maestrichtian.

\section{Gublerina robusta de Klasz}

(Pl. 1, Fig. 7)

Gublerina acuta subsp. robusta de Klasz, 1953, p. 247, pl. 8, figs. 4a-b, 5a-b.

Occurrence. Restricted to the Abathomphalus mayaroensis Zone at Sites 689 and 690. The holotype is from the Maestrichtian "Bucheck Beds", south of Siegsdorf, Bavaria.

\section{Pseudotextularia elegans (Rzehak)}

$$
\text { (Pl. 1, Fig. 16) }
$$

Cuneola elegans Rzehak, 1891, p. 4.

Occurrence. Found only in uppermost Maestrichtian Sample 113689B-25X-5, 105-107 cm. Samples from the same stratigraphic level at Hole $690 \mathrm{C}$ were unavailable for this study. As this species is known to range into Campanian sediments in lower latitude regions, its first occurrence at the Maud Rise is strongly diachronous.

\section{Globigerinelloides impensus Sliter \\ (Pl. 1, Figs. 10-11)}

Globigerinelloides impensus Sliter, 1977, p. 541, pl. 6, figs. 1-3. Krasheninnikov and Basov, 1983, p. 803, pl. 2, figs. 4-6.

Occurrence. This is the nominal taxon of the $G$. impensus Zone, ranging within the latest Campanian-early Maestrichtian at the Maud Rise (LAD in Chron 32N) and the late Campanian-early Maestrichtian at the Falkland Plateau.

\section{Globigerinelloides multispinatus (Lalicker)}

(Pl. 1, Figs. 12-14)

Biglobigerinella multispinatus Lalicker, 1948, p. 624, pl. 92, figs. 1-3.

Occurrence. One of the most common components of late Campanian-Maestrichtian assemblages from the high southern latitudes. Uniand bicameral forms occur in few to high abundance throughout the Maestrichtian sequence at the Maud Rise.

\section{Globigerinelloides subcarinatus (Brönnimann)}

(Pl. 1, Figs. 15-16)

Globigerinella messinae subcarinata Brönnimann, 1952, p. 44-45, pl. 1, figs. 10-11, Text-figs. 21a-m.

Occurrence. Originally described from Maestrichtian strata in Trinidad (Brönnimann, 1952), G. subcarinatus has been reported from mid Campanian through upper Maestrichtian sediments in a number of tropi$\mathrm{cal}$ and subtropical sites. The first appearance of this species in upper Chron $31 \mathrm{R}$ is diachronous in the south polar region, as its distribution at the Maud Rise is limited to the Abathomphalus mayaroensis Zone.

\section{Globigerinelloides sp.}

(Pl. 1, Figs. 8-9)

Remarks. This species differs from Globigerinelloides multispinatus (Lalicker) by its greater number of chambers in the final whorl (commonly 6-7), finer surface ornament, thinner test and broader umbilicus. It is distinguished from $G$. impensus Sliter by having fewer chambers in the final whorl, slightly smaller size, and having a more broadly rounded equatorial periphery.

Occurrence. Sporadically occurs in very rare abundance throughout the Cretaceous at Sites 689 and 690 . This form also occurs in Cores 23 and 24 of DSDP Site 511 on the Falkland Plateau (pers. observ.).

\section{Schackoina multispinata (Cushman and Wickenden)}

$$
\text { (P1. 2, Fig. 1) }
$$

Hantkenina multispinata Cushman and Wickenden, 1930, p. 40, pl. 6, figs. 4-6.

Occurrence. This species occurs in very rare abundance from the base of the Globigerinelloides impensus Zone at both Maud Rise sites up to lower Chron 31R at the base of the Abathomphalus mayaroensis Zone. It is commonly found in Upper Cretaceous sediments worldwide.

\section{Hedbergella holmdelensis Olsson}

(Pl. 2, Figs. 2-4; Pl. 6, Fig. 1)

Hedbergella holmdelensis Olsson, 1964, p. 160, pl. 12, figs. 1-2. not Hedbergella holmdelensis Olsson. Sliter, 1977, p. 542, pl. 3, figs. 1-3.

Remarks. Hedbergella holmdelensis is distinguished from $H$. monmouthensis (Olsson) by its larger size (up to $300 \mu \mathrm{m}$ in diameter), by having a more compressed test and by the asymmetry of the final chamber face. Topotypes of this species were compared with the Maud Rise specimens and found to be identical in external and internal morphology (Huber, 1988b). It differs from $H$. sliteri by its smaller size and narrower, deeper umbilicus.

Occurrence. Very rare at the Maud Rise, occurring in the Globigerinelloides impensus Zone and the lower Globotruncanella havanensis Zone. Re-examination of material from the Falkland Plateau indicates its range extends from Section 36-327A-13R-2 through -12R-2 and Section 71-511-41R-3 through -28R-7, which have been dated as Campanian through early to early middle Maestrichtian (Wind and Wise, 1983). Caron (1985) reported that $H$. holmdelensis ranges from the Coniacian through Maestrichtian, but this extensive range is probably an artifact of confused taxonomic concepts.

\section{Hedbergella monmouthensis (Olsson)}

(Pl. 2, Figs. 6-8; Pl. 6, Fig. 2)

Globorotalia monmouthensis Olsson, 1960, p. 47, pl. 9, figs. 22-24.

not Hedbergella monmouthensis (Olsson). Sliter, 1977, p. 542, pl. 3, figs. 1-3. Krasheninnikov and Basov, 1983, p. 805-806, pl. 6, figs. 5-8. Huber, 1988a, p. 206, figs. 24.14-17. 
Remarks. This species has frequently been confused with similar juvenile forms of other species. It is distinguished by its small size (less than $200 \mu \mathrm{m}$ diameter), chambers that increase moderately in size, and symmetrically globular final chamber face. The ontogenetic morphology of the Maud Rise forms were compared with topotypes (Pl. 6, Fig. 2) of this species and found to be identical.

Occurrence. Incorrect identifications of $H$. monmouthensis have led to uncertainty in its stratigraphic distribution. Robaszynski et al. (1984) suggest that it ranges from the lowermost Campanian through the Maestrichtian, whereas Olsson (1987) maintains that this species evolved from $H$. holmdelensis during the early Maestrichtian. At the Maud Rise, $H$. monmouthensis ranges from the Globigerinelloides impensus Zone through the Abathomphalus mayaroensis Zone. Re-examination of the stratigraphic distribution of $H$. monmouthensis at the Falkland Plateau indicates its first appearance is in upper Campanian Sections 36-327 A13R-2 and 71-511-24R-7.

Hedbergella sliteri $\mathrm{n} . \mathrm{sp}$.

(Pl. 2, Figs. 5, 9-10; Pl. 6, Figs. 4-5)

Hedbergella monmouthensis (Olsson). Webb, 1973b, p. 552, pl. 3, figs. 1-2.

Hedbergella holmdelensis Olsson. Sliter, 1977, p. 542, pl. 2, figs. 1-4. Hedbergella monmouthensis (Olsson). Huber, 1988a, p. 206, figs. 27.1417.

Etymology. Named for W. V. Sliter (USGS, Menlo Park), a pioneer in the study of Late Cretaceous planktonic foraminifer biogeography of the southern South Atlantic.

Diagnosis. Test nearly planispiral to low trochospiral, chambers gradually increasing in size, five to six in final whorl, umbilicus broad and shallow, aperture a low extra-umbilical arch bordered by a narrow porticus near the equatorial periphery.

Description. Test coiled in a low trochospire and sometimes nearly planispiral, often flattened on the spiral side, convex on the umbilical side, average diameter $273 \mu \mathrm{m}$, average breadth $123 \mu \mathrm{m}$. Chambers inflated, slightly reniform to globular, increasing gradually in size, usually five to six in the final whorl, four and one-half to six in the penultimate whorl, 12 to 15 comprising the entire test of adult specimens, final chamber normalform or sometimes kummerform. Proloculus diameter averaging $17 \mu \mathrm{m}$, initial whorl diameter averaging $74 \mu \mathrm{m}$, with a mean of 5.0 chambers in the initial whorl. Sutures strongly depressed, radial and straight on the spiral and umbilical sides. Umbilicus shallow, broad, averaging $28 \%$ of the maximum test diameter. Aperture a low, interiomarginal arch, extra-umbilical, sometimes positioned very near the equatorial periphery, bordered by a narrow porticus. Relict apertures and apertural flaps well-developed. Test surface nearly smooth to finely pustulose, outer wall radial hyaline, finely perforate.

Remarks. Populations of this species were compared with topotypes of $H$. monmouthensis (Olsson) from the Red Bank Formation (New Jersey) and SEM illustrations of $H$. holmdelensis Olsson and $H$. monmouthensis provided by R. K. Olsson (pers. comm., 1987). Hedbergella sliteri differs by its larger size, chambers that increase more gradually in size, fewer number of chambers in the penultimate whorl and broader umbilical region. The frequency of specimens with kummerform final chambers is higher among the Maud Rise assemblages than those of the Falkland Plateau.

Occurrence. At the Maud Rise, the FAD of $H$. sliteri is within lower Chron 32R, and it ranges from the Globotruncanella havanensis Zone through the Abathomphalus mayaroensis Zone, occurring in very rare to common abundance. It is a common component of samples correlated with the $G$. havanensis Zone at the Falkland Plateau, occurring within Cores 36-327A-12 through 36-327A-10, but it is absent from DSDP Site 511 and all samples examined from the Globigerinelloides impensus Zone. Forms described by Webb (1973b) from Lord Howe Rise DSDP Site 208 occur in sediments of middle to late Maestrichtian age. This species is considered to be endemic to the Austral Province.

Holotype. USNM 41770 (Pl. 2, Figs. 5, 9-10). Maximum diameter: $370 \mu \mathrm{m}$, maximum breadth: $155 \mu \mathrm{m}$.

Paratypes. USNM 41771.

Type locality. Maud Rise, southern South Atlantic, Sample 113$690 \mathrm{C}-18 \mathrm{X}-5,46-49 \mathrm{~cm}$.
Archaeoglobigerina australis n. sp.

(Pl. 2, Figs. 11-13, Pl. 3, Figs. 1-7; Pl. 6, Figs. 7-9)

Hedbergella monmouthensis (Olsson), Sliter, 1977, p. 542, pl. 3, figs. 1-3. Krasheninnikov and Basov, 1983, p. 804-805, pl. 6, figs. 5-8. Rugoglobigerina pilula Belford, Sliter, 1977, p. 542, pl. 120, figs. 7-9. Krasheninnikov and Basov, 1983, p. 807, pl. 11, figs. 3-6.

Rugoglobigerina pustulata Brönnimann, Krasheninnikov and Basov, 1983 , p. 806 , pl. 10 , figs. $10-13$.

Rugoglobigerina rotundata Brönnimann, Sliter, 1977, p. 543, pl. 11, figs. 1-3. Krasheninnikov and Basov, 1983, p. 807, pl. 11, figs. 7-11. Huber, 1988a, p. 206, figs. 28.12-14.

Etymology. From australis (latin), referring to the southern latitude region where it is found.

Diagnosis. Test biconvex, moderate to high spired, chambers strongly inflated, globular, final whorl chambers on adult specimens four to six, increasing moderately in size, adult apertures umbilical to slightly extraumbilical with a broad flap, surface composed of randomly situated pustules.

Description. Test coiled in a moderate to high spire, unequally biconvex, spiral side usually more convex than umbilical side, average diameter of adult specimens $280 \mu \mathrm{m}$, average breadth $150 \mu \mathrm{m}$. Chambers strongly inflated, globular, increasing moderately in size with four to five and one-half in the penultimate whorl, increasing gradually in size with three and three-quarters to five and three-quarters in the ultimate whorl, 12 to 15 comprising the tests of adult specimens, final chambers usually kummerform. Proloculus diameter of adult specimens averaging $16 \mu \mathrm{m}$, initial whorl diameter averaging $71 \mu \mathrm{m}$, with a mean of 4.4 chambers in the initial whorl. Sutures moderately to strongly depressed, radial and straight on both the spiral and umbilical sides. Apertures of juvenile specimens extra-umbilical in position, having greater width than height, bordered by a narrow, thickened lip. Apertures of adult specimens umbilical to slightly extra-umbilical in position, often bordered by a broad flap that may completely extend across the umbilicus, with relict apertural flaps sometimes coalescing to form a pseudo-tegillum. Umbilicus deep, narrow to broad, comprising an average of $28 \%$ of the maximum test diameter. Test surface covered with fine to coarse, randomly situated pustules, surface of final chamber usually with finer pustulose ornament than previous chambers. Outer wall radial hyaline and finely perforate.

Remarks. Although end member morphotypes included in this species show considerable differences in chamber development and apertural characteristics (e.g., compare Pl. 2, Figs. 11-12 with Pl. 3, Figs. $2-4)$, no distinct populations could be recognized as a separate species in the Maud Rise and Falkland Plateau assemblages. Serial dissection of large, adult specimens and X-ray micrographs (Huber, 1987, 1988b) have revealed penultimate whorl morphologies identical to small forms (see Pl. 2, Figs. 11-13; Pl. 6, Figs. 7-9), here considered as juvenile specimens of $A$. australis.

Gerontic forms of $A$. australis resemble specimens of $A$. bosquensis Pessagno that were described from Santonian sediments in the western Gulf Coastal Plain (Pessagno, 1967) and the Falkland Plateau (Sliter, 1977; Krasheninnikov and Basov, 1983). The Gulf Coast holotype and paratype of $A$. bosquensis differ from $A$. australis by having a smoother test surface and lacking kummerform chambers and apertural flaps. However, poor preservation of the type material and uncertainty of the morphologic variability among Gulf Coast populations of $A$. bosquensis preclude an adequate comparison of these taxa. Falkland Plateau specimens described as $A$. bosquensis, which are very well preserved and occur in high abundance, do not bear aperiural flaps, are generally higher spired and have a narrower, deeper umbilicus than most forms of A. australis, although some forms of the latter species (e.g., Pl. 3, Fig. 7) are very similar. The stratigraphic distribution of these two species and their morphologic similarity suggest that $A$. australis is a descendant of A. bosquensis.

No specimens with tegilla, imperforate peripheral margins, peripheral keels, or meridionally arranged costellae have been found. Therefore, this species is not placed in Rugoglobigerina or Rugotruncana. Inclusion in Archaeoglobigerina differs from the original description of that genus, which suggests that tegilla should be observed in "perfectly preserved specimens" (Pessagno, 1967, p. 315). Because this structure is 
absent from the Gulf Coast type species of Archaeoglobigerina ( $A$. blowi Pessagno) and the holotype of Archaeoglobigerina bosquensis, it is not considered as a primary generic character. Either the definition of this genus needs to be modified, or a new genus should be created to accommodate the non-keeled, non-tegillate forms.

Occurrence. Archaeoglobigerina australis dominates the Maud Rise planktonic foraminifer assemblages from the Globigerinelloides impensus Zone through to the middle Abathomphalus mayaroensis Zone. It is also a dominant component of late Campanian through early Maestrichtian assemblages at Falkland Plateau DSDP Sites 327 and 511 and is very rare on Seymour Island (see synonymy above). Its first appearance at the Falkland Plateau is in lower Campanian Sample 71-511-30-4, 61-63 cm (pers. observ.).

Holotype. USNM 415772 (Pl. 3, Figs. 2-4). Maximum diameter: $334 \mu \mathrm{m}$, maximum breadth: $190 \mu \mathrm{m}$.

Paratypes. USNM 415773.

Type locality. Maud Rise, southern South Atlantic, Sample 113$690 \mathrm{C}-19 \mathrm{X}-3,119-123 \mathrm{~cm}$.

Archaeoglobigerina mateola $\mathrm{n} . \mathrm{sp}$.

(Pl. 3, Figs. 8-10; Pl. 4, Figs. 1-3; Pl. 6, Fig. 6)

Rugoglobigerina? sp. 2, Huber, 1988a, p. 207, figs. 31.12, 15-16.

Etymology. From mateus (latin), a medieval war club with a blunt, spiny terminus.

Diagnosis. Test moderate to high spired, often unequally biconvex, chambers increasing moderately in size, three and three-quarters to four and one-half in final adult whorl, adult aperture umbilical, often covered by a flap or thickened bulla, final chambers usually kummerform, surface distinctly ornamented by coarse pustules or long, narrow spines.

Description. Test coiled in a moderate to high spire, equally to unequally biconvex, spiral side often more convex than umbilical side, average diameter of adult specimens $280 \mu \mathrm{m}$, average breadth $190 \mu \mathrm{m}$. Chambers globular, inflated, increasing moderately in size, three and threequarters to four and one-half in the final adult whorl, four to four and one-half in the penultimate whorl, 10-12 comprising the tests of adult specimens, final chambers usually kummerform. Proloculus diameter averaging $17 \mu \mathrm{m}$, initial whorl diameter averaging $74 \mu \mathrm{m}$, with a mean of 4.5 chambers in the initial whorl. Sutures radial and straight, strongly depressed on umbilical side, moderately depressed on spiral side. Aperture umbilical in position on adult specimens, usually obscured by a broad flap or thickened umbilical bulla. Apertures of juvenile specimens umbilical to extra-umbilical, having greater width than height. Surface distinctly ornamented with randomly situated, large pustules or high, narrow spines on adult specimens, smooth to finely pustulose on juveniles. Outer wall radial hyaline and finely perforate.

Remarks. This species has a very unusual external morphology compared with other known Late Cretaceous planktonic foraminifer taxa. Similarity in the ontogenetic development of this species suggests a close ancestral relationship with $A$. australis (Huber, 1988b). Inclusion in Archaeoglobigerina is primarily because of the globigerine chamber arrangement and absence of meridional costellae. Neither tegilla nor peripheral keel bands were observed in the Maud Rise populations, however, so similarity to the original definition of Archaeoglobigerina (see Pessagno, 1967, p. 315) is limited.

Occurrence. At the Maud Rise, this species occurs in very rare abundance in the Globigerinelloides impensus Zone and lower Globotruncana havanenesis Zone, and rare to common abundance through the Abathomphalus mayaroensis Zone. Very rare occurrences of this species were reported by Huber (1988a; see synonymy above) from one sample in the lower Maestrichtian of Seymour Island (Antarctic Peninsula).

Holotype. USNM 415774 (Pl. 3, Figs. 8-10). Maximum diameter: $301 \mu \mathrm{m}$, maximum breadth: $215 \mu \mathrm{m}$.

Paratypes. USNM 415775.

Type locality. Maud Rise, southern South Atlantic, Sample 113$690 \mathrm{C}-20 \mathrm{X}-3,116-118 \mathrm{~cm}$.

\section{Rugotruncana circumnodifer (Finlay)}

(Pl. 4, Figs. 4-10; Pl. 6, Fig. 3)

Globigerina circumnodifer Finlay, 1940, p. 469, pl. 65, figs. 150-157. Globotruncana (Rugotruncana) circumnodifer (Finlay). Webb, 1973b, p. 552 , pl. 4 , figs. $1-4$.
Remarks. This species is distinguished by having strongly inflated chambers numbering four to five and one-half in the final whorl and paired keels on the equatorial periphery. The keels are usually not visible on the ultimate chambers and are sometimes only expressed by an imperforate peripheral band (e.g., Pl. 4, Figs 8-9). Surface ornament varies from randomly situated, small pustules to well-developed costellae aligned in a meridional pattern. Tegilla are usually preserved on the Maud Rise specimens.

Occurrence. This species was first described by Finlay (1940) from New Zealand where it occurs with Abathomphalus mayaroensis (Webb, 1971). Rugotruncana circumnodifer was also reported from DSDP Site 208 in the Tasman Sea (Webb, 1973b). A single specimen resembling this species, referred to as Rugotruncana cf. $R$. circumnodifer, was found on Seymour Island (Antarctic Peninsula) in the lower Hedbergella monmouthensis Zone (Huber, 1988a). At the Maud Rise, $R$. circumnodifer first appears in Chron $32 \mathrm{~N}$, within the upper Globotruncanella havanensis Zone and ranges through the Abathomphalus mayaroensis Zone. It is uncertain whether $R$. circumnodifer was restricted to the Austral Province, as it may have been confused with other globular, double keeled species, such as Rugotruncana subpennyi (Gandolfi) and Globotruncana subcircumnodifer Gandolfi, Olsson (1964, pl. 6, figs. 5a-c).

\section{Globotruncanella citae (Bolli)}

Globotruncana citae Bolli, 1951, p. 197, pl. 35, figs. 4-6.

Occurrence. Restricted to the upper Abathomphalus mayaroensis Zone at the Maud Rise. Its earlier (middle Maestrichtian) first appearance at lower latitude sites suggests a time-transgressive migration from the tropics toward the south polar region during the late Maestrichtian.

\section{Globotruncanella havanensis (Voorwijk) \\ (Pl. 5, Figs. 1-2)}

Globotruncana havanensis Voorwijk, 1937, p. 195, pl. 1, figs. 25-26.

Occurrence. This is the nominal taxon of the $G$. havanensis Zone at the Maud Rise. It appears in lower Chron 32R, above the LAD of Globigerinelloides impensus in Samples 113-689B-30X-1, 83-85 cm and $113-690 \mathrm{C}-21 \mathrm{X}-5,118-122 \mathrm{~cm}$ and ranges into the Abathomphalus mayaroensis Zone, occurring in very rare to rare abundance. Caron (1985) and others report that $G$. havanensis ranges from the uppermost Campanian through the Maestrichtian.

\section{Globotruncanella petaloidea (Gandolfi) (Pl. 4, Fig. 11)}

Globotruncana (Rugoglobigerina) petaloidea Gandolfi, 1955, p. 52, pl. 3 , fig. 13.

Globotruncanella? sp., Huber, 1988a, p. 208, figs. 31.4, 31.7-31.8.

Occurrence. At the Maud Rise, this species ranges from upper Chron $32 \mathrm{~N}$ in the upper Globotruncanella havanensis Zone through the $A b a-$ thomphalus mayaroensis Zone. A single specimen of G. petaloidea, previously identified as Globotruncanella? sp., occurs only in the uppermost Maestrichtian beds on Seymour Island in the northern Antarctic Peninsula (Huber, 1988a).

\section{Abathomphalus intermedius (Bolli)}

$$
\text { (Pl. 5, Figs. 5-6) }
$$

Globotruncana intermedia Bolli, 1951, p. 197-198, pl. 35, figs. 7-9.

Occurrence. This species appears just below the FAD of $A$. mayaroensis in Chron 30R at Maud Rise Sites 689 and 690, and occurs in very rare abundance. Caron (1985) reports that the stratigraphic distribution of $A$. intermedius is limited to the late Maestrichtian, ranging from the middle of the tropical Gansserina gansseri Zone through the A. mayaroensis Zone.

Abathomphalus mayaroensis (Bolli)

$$
\text { (Pl. 5, Figs. 3-4) }
$$

Globotruncana mayaroensis Bolli, 1951, p. 190, 198, pl. 35, figs. 10-12.

Occurrence. This is the nominal taxon for the $A$. mayaroensis Zone, which is recognized worldwide as being late Maestrichtian in age. The FAD of this species at the Maud Rise is in the middle of Chron 31R and it ranges up to the Cretaceous-Tertiary boundary at both sites. 


\section{Globotruncana bulloides Vogler}

(Pl. 5, Figs. 9-11)

Globotruncana bulloides Vogler, 1941, p. 287, pl. 23, figs. 32-39.

Occurrence. This species first appears in the middle of Chron $32 \mathrm{~N}$ in the Globotruncanella havanensis Zone and occurs sporadically and in very rare abundance in the Abathomphalus mayaroensis Zone at the Maud Rise. Globotruncana bulloides is reported as ranging from the $G$. elevata Zone to within the $A$. mayaroensis Zone at lower latitude sites (Caron, 1985). Thus, its first occurrence in the middle Maestrichtian at the Maud Rise considerably post-dates its first evolutionary appearance in tropical to subtropical regions.

\section{Globotruncana subcircumnodifer (Gandolfi)} (Pl. 5, Figs. 7-8, 12)

Globotruncana (Rugoglobigerina) subcircumnodifer Gandolfi, 1955, p. 44 , pl. 2, figs. 7a-c.

Occurrence. This species ranges from the middle of Chron $32 \mathrm{~N}$ in the upper part of the Globotruncana havanensis Zone through the Abathomphalus mayaroensis Zone at the Maud Rise, occurring in very rare to rare abundance. As it is reported to first appear in the upper Globotruncana calcarata Zone (upper Campanian) at lower latitude sites (Caron, 1985), the FAD of G. subcircumnodifer in the southern South Atlantic is regarded as diachronous.

\section{ACKNOWLEDGMENTS}

I am very grateful to the co-chief scientists and shipboard scientific party of ODP Leg 113 for making samples available so that I could pursue this study. I would like to thank Peter N. Webb (The Ohio State University) for reviewing an earlier draft of this manuscript, the reviewers William V. Sliter (USGS Menlo Park) and Bruce A. Masters (Amoco Production Research) for their many helpful comments, Alexandra J. Nederbragt (Vrije Universiteit) for beneficial advice on the heterohelicid taxonomy, and Mary Parrish (Smithsonian Institution) for drafting Figure 9. This research was supported by funds donated to the Friends of Orton Hall (The Ohio State University).

\section{REFERENCES}

Barron, E. J., 1987. Global Cretaceous paleogeography-International Geologic Correlation Program Project 191. Palaeogeogr., Palaeoclimatol., Palaeoecol., 59:207-216.

Belford, D. J., 1960. Upper Cretaceous foraminifera from the Toolonga calcilutite and Gingin chalk, Western Australia. Aust. Bur. Miner. Resour., Geol. and Geophys., Bull., 57:1-198.

1983. Note on costellate planktonic foraminifera, and the generic designation of Late Cretaceous forms from Western Australia. In Palaeontological Papers, 1983, Aust. Bur. Miner. Resour., Bull., 217:1-9.

Berggren, W. A., Hamilton, N., Johnson, D. A., Pujol, C., Weiss, W. Cepek, P., and Gombos, A. M., Jr., 1983. Magnetobiostratigraphy of Deep Sea Drilling Project Leg 72, Sites 515-518, Rio Grande Rise (South Atlantic). In Barker, P. F., Carlson, R. L., Johnson, D. A., et al., Init. Repts. DSDP, 72: Washington (U.S. Govt. Printing Office), 939-947.

Boersma, A., 1984. Cretaceous-Tertiary planktonic foraminifers from the southeastern Atlantic, Walvis Ridge area, Deep Sea Drilling Project Leg 74. In Moore, T. C., Jr., Rabinowitz, P. D., et al., Init. Repts. DSDP, 74: Washington (U.S. Govt. Printing Office), 501-523.

Boersma, A., and Shackleton, N. J., 1981. Oxygen- and carbon-isotope variations and planktonic foraminifer depth habitats, Late Cretaceous to Paleocene, central Pacific, Deep Sea Drilling Project Sites 463 and 465. In Thiede, J., Vallier, T. L., et al., Init. Repts. DSDP, 62: Washington (U.S. Govt. Printing Office), 513-526.

Bolli, H. M., 1951. The genus Globotruncana in Trinidad, B.W.I. J. Paleontol., 25:187-197.

Brönnimann, P., 1952. Globigerinidae from the Upper Cretaceous (Cenomanian-Maestrichtian) of Trinidad, B.W.I. Bull. Am. Paleontol., 34:1-70.

Caron, M., 1985. Cretaceous planktic foraminifera. In Bolli, H. M., Saunders, J. B., and Perch-Nielsen, K., Plankton Stratigraphy, Cambridge (Cambridge University Press), 17-86.
Caron, M., and Homewood, P., 1983. Evolution of early planktic foraminifera. Mar. Micropaleontol., 7:453-462.

Ciesielski, P. F., Sliter, W. V., Wind, F. H., and Wise, S. W., Jr., 1977. Paleoenvironmental analysis and correlation of a Cretaceous Islas Orcadas core from the Falkland Plateau, southwest Atlantic. Mar. Micropaleontol., 2:27-34.

Cifelli, R., and Scott, G., 1986. Stratigraphic record of Neogene Globorotalid radiation (Planktonic Foraminiferida). Smithsonian Contributions to Paleobiology, 58:1-101.

Cushman, J. A., 1933. Some new foraminiferal genera. Cushman Lab. Foraminiferal. Res., Contrib., 9:32-38.

1938. Cretaceous species of Guembelina and related genera. Cushman Lab. Foraminiferal. Res., Contrib., 14:2-28.

Cushman, J. A., and Wickenden, R. T. D., 1928. A new foraminiferal genus from the Upper Cretaceous. Cushman Lab. Foraminiferal. Res., Contrib., 4:12-13.

Douglas, R. G., 1969. Upper Cretaceous planktonic foraminifera in northern California. Micropaleontology, 15:151-209. 1972. Paleozoogeography of Late Cretaceous planktonic foraminifera in North America. J. Foraminiferal Res., 2:14-34.

Douglas, R. G., and Savin, S. M., 1975. Oxygen and carbon isotope analyses of Tertiary and Cretaceous microfossils from Shatsky Rise and other sites in the North Pacific Ocean. In Larson, R. L., Moberly, R., et al., Init. Repts. DSDP, 32: Washington (U.S. Govt. Printing Office), 509-520.

Ehrenberg, C. G., 1840. Uber die Bildung der Kriedefelsen und des Kreidemergels durch unsichtbare Organismen. K. Akad. Wiss., Berlin, Physik. Abh. (1838), 59-147.

Finlay, H. J., 1940. New Zealand Foraminifera: key species in stratigraphy. Trans. Roy. Soc. New Zealand, 69:448-472.

Gandolfi, R., 1955. The genus Globotruncana in northeastern Colombia. Bull. Am. Paleontol., 36:1-118.

Haq, B. U., Hardenbol, J., and Vail, P. R., 1987. The new chronostratigraphic basis of Cenozoic and Mesozoic sea level cycles. Cushman Found. Foraminiferal. Res., Spec. Pub., 24, Fig. 2.

Huber, B. T., 1987. Ontogenetic morphometrics of some Upper Cretaceous foraminifera from the southern high latitudes. Antarct. $J$. U.S., 22:(5)15-17.

1988a. Upper Campanian-Paleocene foraminifera from the James Ross Island region (Antarctic Peninsula). In Feldmann, R. M., and Woodburne, M. O., (Eds.), Geology and Paleontology of Seymour Island, Antarctica. Geol. Soc. Am., Mem. Ser., 169:163-251. 1988b. Upper Campanian-Maestrichtian foraminifers of the high southern latitudes: ontogenetic morphometric systematics, biostratigraphy, and paleobiogeography [Ph.D. Dissert.]. The Ohio State Univ., Columbus.

in press. Planktonic foraminifer biostratigraphy of Campanian-Maestrichtian sediments from ODP Leg 114 Sites 698 and 700, southern South Atlantic. In Ciesielski, P. F., Kristofferson, Y., Clement, B., et al., Proc. ODP, Sci. Results, 114: College Station, TX (Ocean Drilling Program).

Keating, B., Helsley, C. E., and Pessagno, E. A., 1975. Late Cretaceous reversal sequence. Geology, 3:73-76.

Kent, D. V., and Gradstein, F. M., 1985. A Cretaceous and Jurassic geochronology. Geol. Soc. Am. Bull., 96:1419-1427.

Klasz, I. de, 1953. Einige neue oder wenig bekannte Foraminiferen aus der helvetischen Oberkreide der bayerischen Alpen südlich Traunstein (Oberbayern): Geol. Bavarica, 17:233-244.

Krasheninnikov, V. A., and Basov, I. A., 1983. Stratigraphy of Cretaceous sediments of the Falkland Plateau based on planktonic foraminifers, Deep Sea Drilling Project, Leg 71. In Ludwig, W. J., Krasheninnikov, V. A., et al., Init. Repts. DSDP, 71: Washington (U.S. Govt. Printing Office), 789-820.

1986. Late Mesozoic and Cenozoic stratigraphy and geological history of the South Atlantic high latitudes. Palaeogeogr., Palaeoclimatol., Palaeoecol., 55:145-188.

Lalicker, C. G., 1948. A new genus of Foraminifera from the Upper Cretaceous. J. Paleontol., 22:624.

Loeblich, A. R., Jr., and Tappan, H., 1988. Foraminiferal Genera and Their Classification (Volume I-II). New York (Van Nostrand Reinhold Co.).

Monechi, S., and Thierstein, H. R., 1985. Late Cretaceous-Eocene nannofossil and magnetostratigraphic correlations near Gubbio, Italy. Mar. Micropaleontol., 9:419-440. 
Olsson, R. K., 1964. Late Cretaceous planktonic Foraminifera from New Jersey and Delaware. Micropaleontology, 10:157-188.

Olsson, R. K., and Wise, S. W., Jr., 1987. Upper Maestrichtian to middle Eocene stratigraphy of the New Jersey slope and coastal plain. In van Hinte, J. E., Wise, S. W., Jr., et al., Init. Repts. DSDP, 93: Washington (U.S. Govt. Printing Office), 1343-1365.

Pessagno, E. A., Jr., 1967. Upper Cretaceous planktonic foraminifera from the western Gulf Coastal Plain. Palaeontograph. Am., 5:245445.

Premoli Silva, I., 1977. Upper Cretaceous-Paleocene magnetic stratigraphy at Gubbio, Italy: II. Biostratigraphy. Geol. Soc. Am. Bull., 88: 371-374.

Premoli Silva, I., and Boersma, A., 1977. Cretaceous planktonic foraminifers-DSDP Leg 39 (South Atlantic). In Supko, P. R., PerchNielsen, K., et al., Init. Repts. DSDP, 39: Washington (U.S. Govt. Printing Office), 615-641.

Rzehak, A., 1891. Die Foraminiferefauna der alttertiären Ablagerungen von Bruderndorf in Nieder-Oesterreich, mit Berüchsichtigung des angeblichen Kreidvorkommens von Leitzersdorf. Naturhist. Hofmuseum, Wien, Annalen, 6:1-12.

Scheibnerova, V., 1971. Foraminifera and their Mesozoic biogeoprovinces. Rec. Geol. Surv. New South Wales, 13:135-174.

, 1973. Non-tropical Cretaceous foraminifera in Atlantic deepsea cores and their implications for continental drift and paleoceanography of the South Atlantic Ocean. Rec. Geol. Surv. New South Wales, 15:19-46.

Sliter, W. V., 1977. Cretaceous foraminifera from the southwest Atlantic Ocean, Leg 36, Deep Sea Drilling Project. In Barker, P. F., Dalziel, I.W.D., et al., Init. Repts. DSDP, 36: Washington (U.S. Govt. Printing Office), 519-573.

1989. Biostratigraphic zonation for Cretaceous planktonic foraminifers examined in thin section. J. Foraminiferal. Res., 19:1-19.

Smith, C. H., and Poore, R. Z., 1984. Upper Maastrichtian and Paleocene planktonic foraminiferal biostratigraphy of the northern Cape Basin, Deep Sea Drilling Project Hole 524. In Hsü, K. J., LaBrecque, J. L., et al., Init. Repts. DSDP, 73: Washington (U.S. Govt. Printing Office), 449-457.
Stenestad, E., 1968. Three new species of Heterohelix Ehrenberg from the Upper Senonian of Denmark. Medd. Dansk Geol. Foren., 18: 64-74.

Vogler, J., 1941. Ober-Jura und Kreide von Misol. In Boehm, G., and Wanner, J., Beitrage zur Geologie von Niederlandisch-Indian. $\mathrm{Pa}$ laeontographica, Suppl. bd. 4, Abt. 4, 243-293.

Voorwijk, G. H., 1937. Foraminifera from the Upper Cretaceous of Habana, Cuba. K. Ned. Akad. Wet., Proc. sec. sci., 40:190-198.

Webb, P. N., 1971. New Zealand Late Cretaceous (Haumurian) foraminifera and stratigraphy: a summary. New Zealand J. Geol. Geophys., 14:795-828.

1973a. Preliminary comments on Maastrichtian-Paleocene foraminifera from Lord Howe Rise, Tasman Sea. Proc. Oceanog. South Pacific, Wellington (UNESCO, 1972), 144-146.

1973b. Upper Cretaceous-Paleocene foraminifera from Site 208 (Lord Howe Rise, Tasman Sea), DSDP, Leg 21. In Burns, R. E., Andrews, J., et al., Init. Repts. DSDP, 21: Washington (U.S. Govt. Printing Office), 541-573.

Wind, F. H., and Wise, S. W., Jr., 1983. Correlation of upper Campanian-lower Maastrichtian calcareous nannofossil assemblages in drill and piston cores from the Falkland Plateau, southwest Atlantic Ocean. In Ludwig, W. J., Krasheninnikov, V. A., et al., Init. Repts. DSDP, 71: Washington (U.S. Govt. Printing Office), 551-563.

Wolfe, J. A., 1987. Late Cretaceous-Cenozoic history of deciduousness and the terminal Cretaceous event. Paleobiology, 13:215-226.

Worsely, T., and Martini, E., 1970. Late Maestrichtian nannoplankton provinces. Nature, 225:1242-1243.

Wright, C. A., and Apthorpe, M., 1976. Planktonic foraminiferids from the Maestrichtian of the northwest shelf, Western Australia. J. Foraminiferal Res., 6:228-240.

Date of initial receipt: 28 September 1988

Date of acceptance: 30 June 1989

Ms 113B-135 


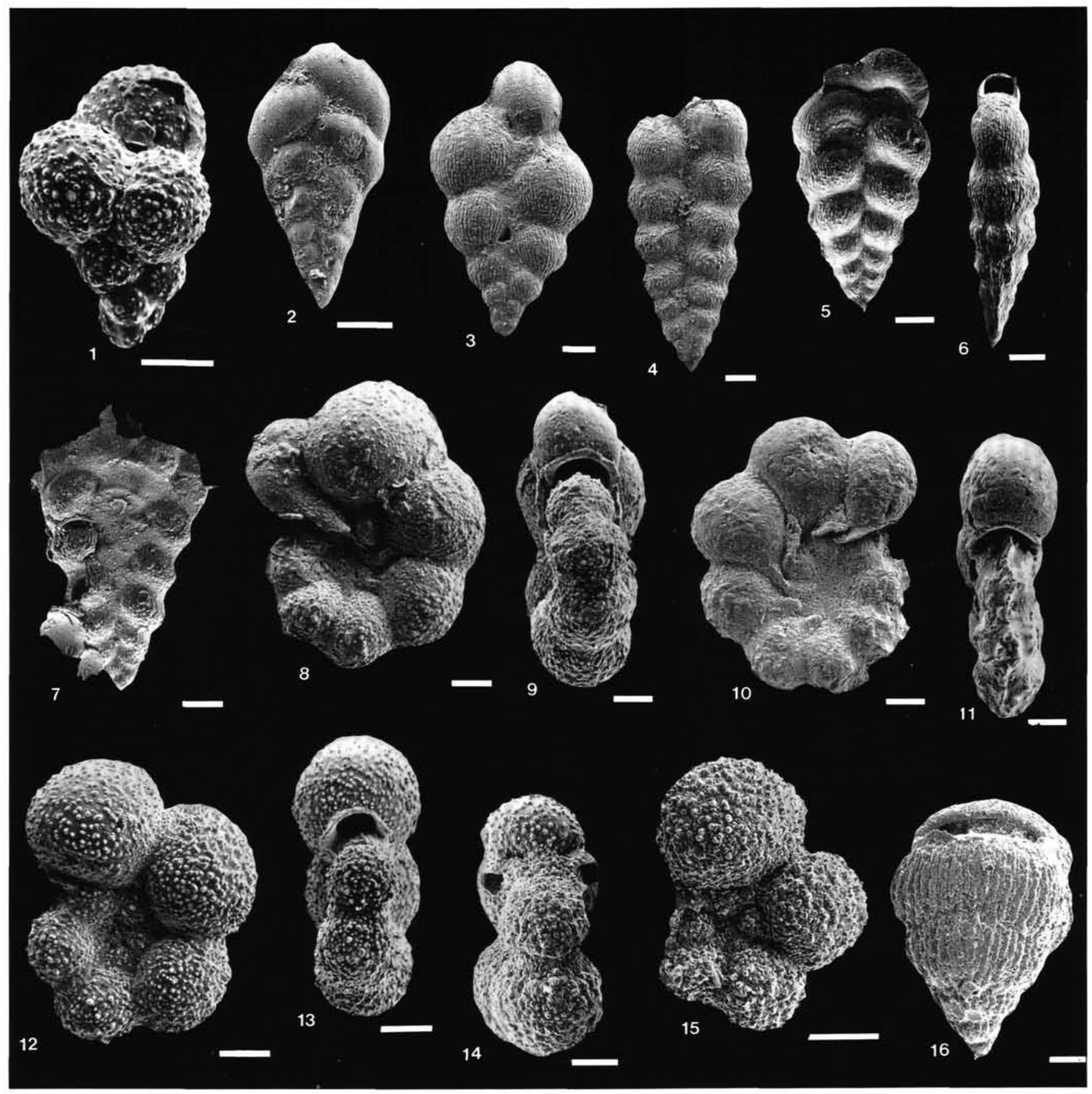

Plate 1. 1. Guembelitria cretacea Cushman, Sample 113-690C-20X-3, 116-118 cm. 2. Heterohelix dentata Stenestad, Sample 113-690C-19X-1, 119-123 cm. 3. Heterohelix globulosa (Ehrenberg), Sample 113-690C-17X-3, 119-123 cm. 4. Heterohelix globulosa (Ehrenberg), Sample 113690C-19X-1, 119-123 cm. 5-6. Heterohelix planata (Cushman), Sample 113-690C-20X-3, 116-118 cm. 7. Gublerina robusta de Klasz, Sample $113-690 \mathrm{C}-18 \mathrm{X}-4,95-99 \mathrm{~cm}$. 8, 9. Globigerinelloides sp., Sample 113-689B-30X-3, 78-83 cm. 10. Globigerinelloides impensus Sliter, Sample 113-690C-22X-4, 118-122 cm. 11-12. Globigerinelloides multispinatus (Lalicker), Sample 113-690C-20X-5, 108-110 cm. 13, 14. Globigerinelloides subcarinatus (Brönnimann), Sample 113-690C-17X-3, 119-123 cm. 15, 16. Pseudotextularia elegans (Rzehak), Sample 113-689B-25X-5, $105-107 \mathrm{~cm}$. Scale bar for Figure 1 is $25 \mu \mathrm{m}$ and for Figures 2-16 is $50 \mu \mathrm{m}$. 


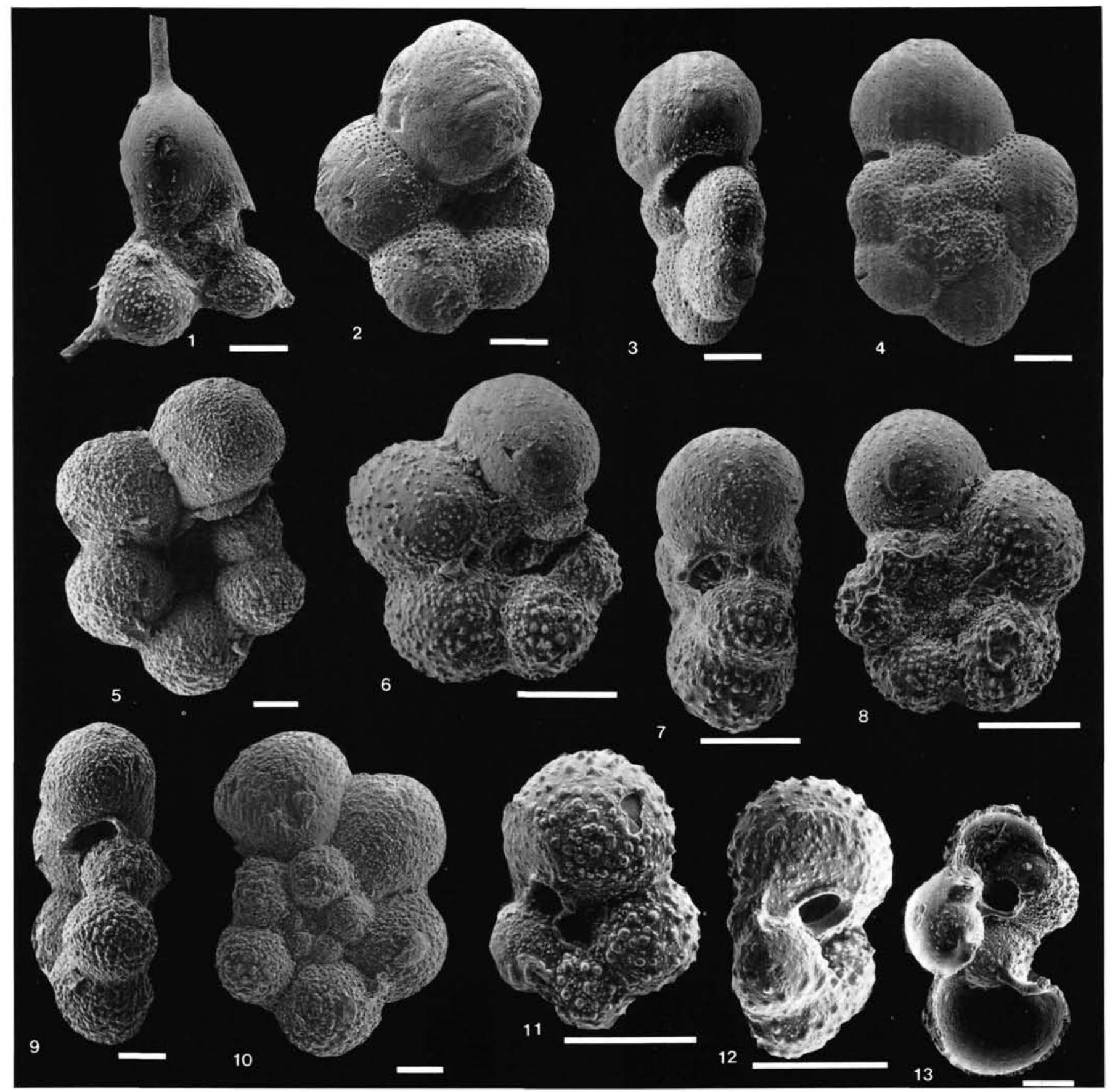

Plate 2. 1. Schackoina multispinata (Cushman and Wickenden), Sample 113-690C-20X-5, 108-110 cm. 2-4. Hedbergella holmdelensis Olsson, Sample 113-690C-21X-4, 118-122 cm. 5, 9-10. Hedbergella sliteri $\mathrm{n}$. sp., holotype, Sample 113-690C-18X-5, 46-49 cm. 6-8. Hedbergella monmouthensis (Olsson), Sample 113-690C-20X-5, 108-110 cm. 11-12. Archaeoglobigerina australis $\mathrm{n}$. sp., neanic specimen, Section 113-690C19X, CC. 13. Archaeoglobigerina australis n. sp., Section 113-690C-20X-3. View with final adult whorl removed, showing similarity of penultimate whorl chambers to neanic specimen of Figures 11-12. Scale bar for Figures 1-13 is $50 \mu \mathrm{m}$. 


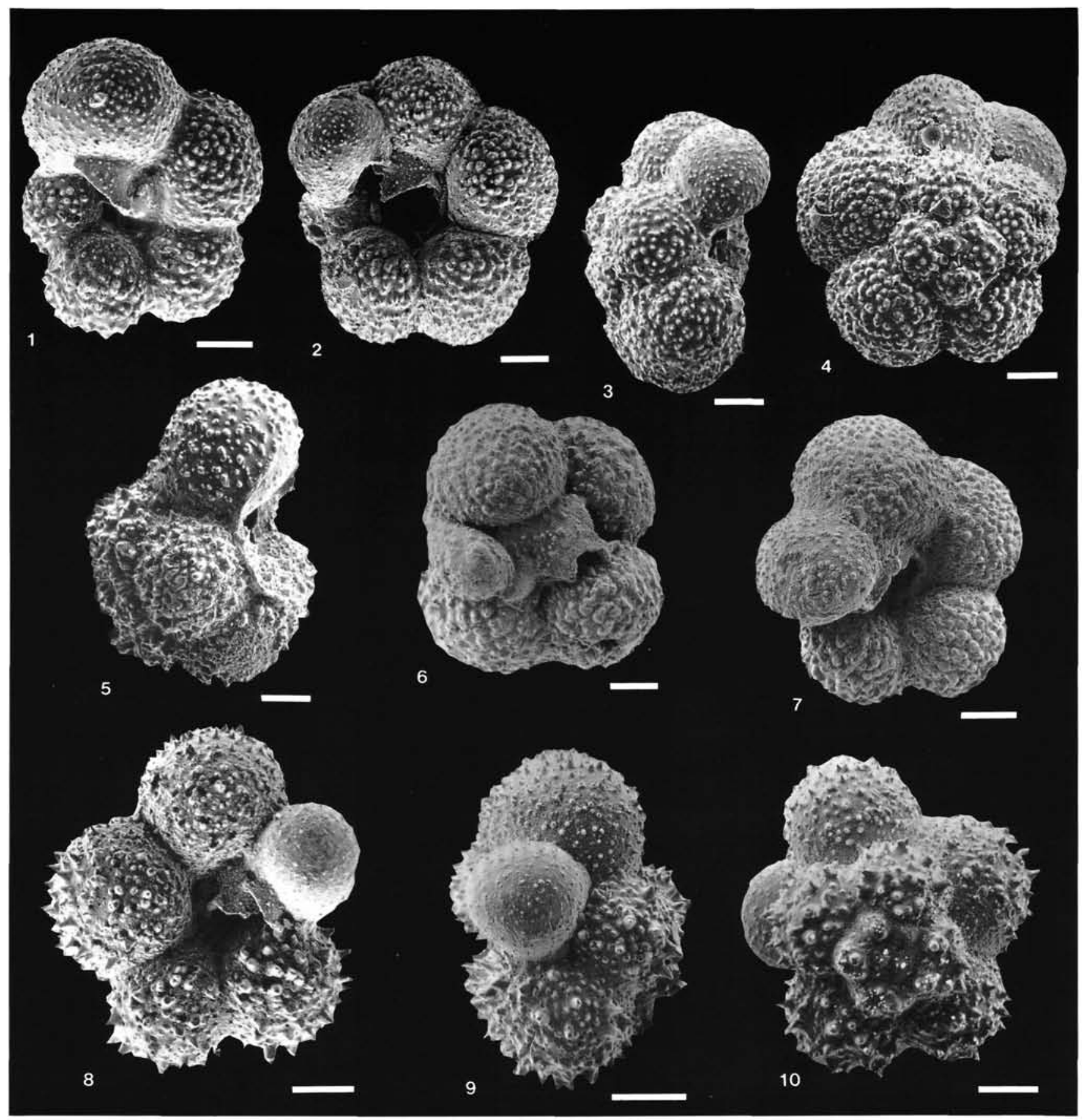

Plate 3. 1. Archaeoglobigerina australis n. sp., s.s., Sample $113-690 \mathrm{C}-19 \mathrm{X}-3,119-123 \mathrm{~cm}$. Note the considerable variability of chamber development, umbilical size, and apertural flaps. 2-4. Archaeoglobigerina australis n. sp., holotype, Sample 113-690C-19X-3, 113-123 cm. 5. Archaeoglobigerina australis n. sp., s.1., Sample 113-690C-19X-3, 119-123 cm. 6. Archaeoglobigerina australis n. sp., s.1., Sample 113-689B-30X-3, 83-87 cm. 7. Archaeoglobigerina australis n. sp., s.1., Sample 113-689B-28X-3, 83-87 cm. 8-10. Archaeoglobigerina mateola n. sp., holotype, Sample $113-690 \mathrm{C}-20 \mathrm{X}-3,119-123 \mathrm{~cm}$. Scale bar for Figures $1-10$ is $50 \mu \mathrm{m}$. 


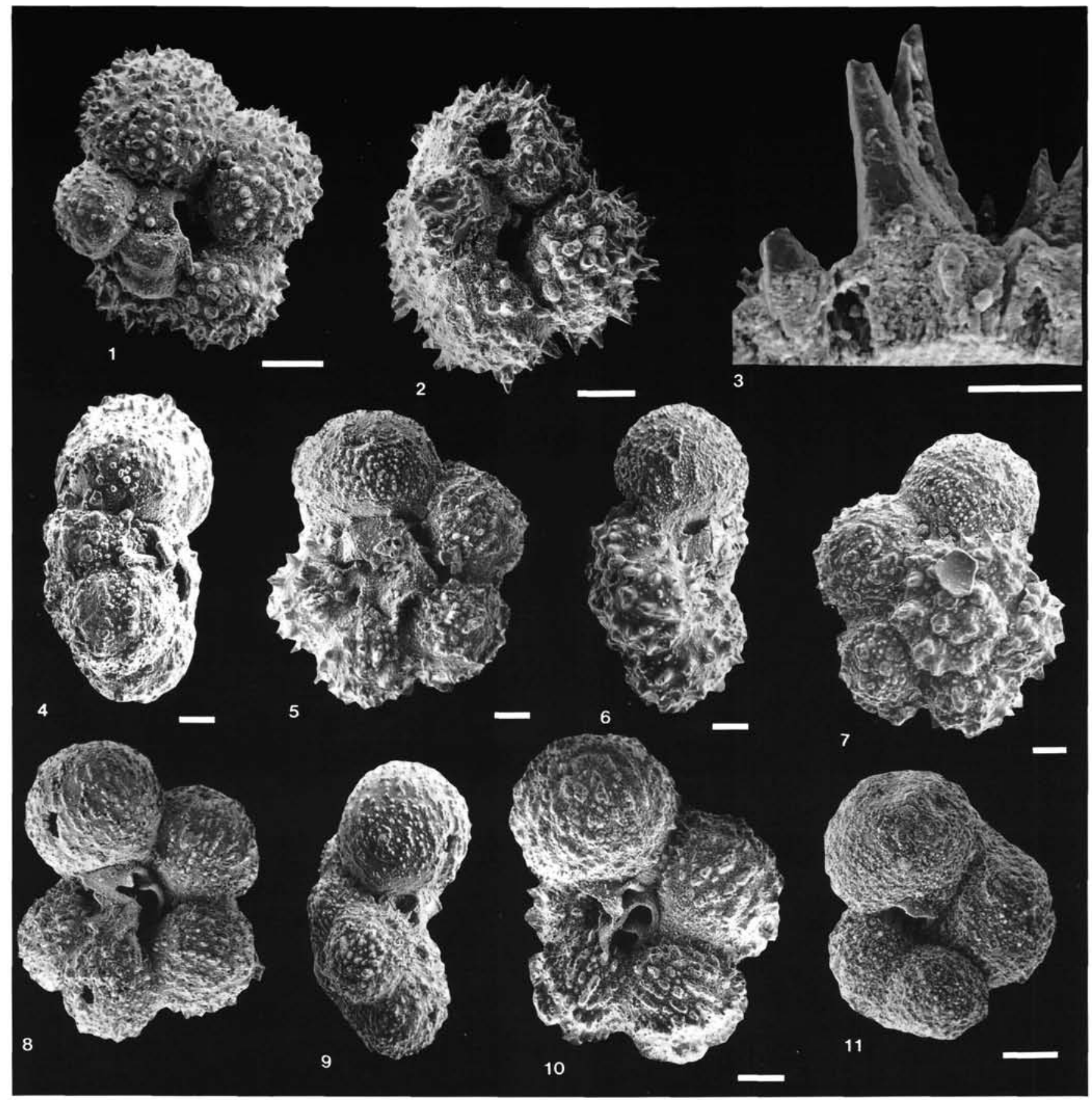

Plate 4. 1. Archaeoglobigerina mateola $\mathrm{n}$. sp., Sample 113-690C-20X-3, 119-123 cm. 2. Archaeoglobigerina mateola n. sp., Sample 113-689B$28 \mathrm{X}-1,76-80 \mathrm{~cm}$. 3. Archaeoglobigerina mateola n. sp., Sample 113-690C-18X-2, 99-103 cm. Enlarged cross-sectional view of the outer wall showing microstructure of distinctive large spines that characterize this species. 4. Rugotruncana circumnodifer (Finlay), Sample 113-690C-17X-3, 119-123 cm. 5-7. Rugotruncana circumnodifer (Finlay), Sample 113-690C-19X-3, 119-123 cm. 8-9. Rugotruncana circumnodifer (Finlay), Sample 113-690C-18X-5, 46-49 cm. Note the absence of a visible keel, but presence of an imperforate peripheral band. 10. Rugotruncana circumnodifer (Finlay), Sample 113-690C-17X-3, 119-123 cm. 11. Globotruncanella petaloidea (Gandolfi), Sample 113-690C-18X-1, 119-123 cm. Scale bar for Figures $1-2,4-11$ is $50 \mu \mathrm{m}$ and for Figure 3 is $10 \mu \mathrm{m}$. 


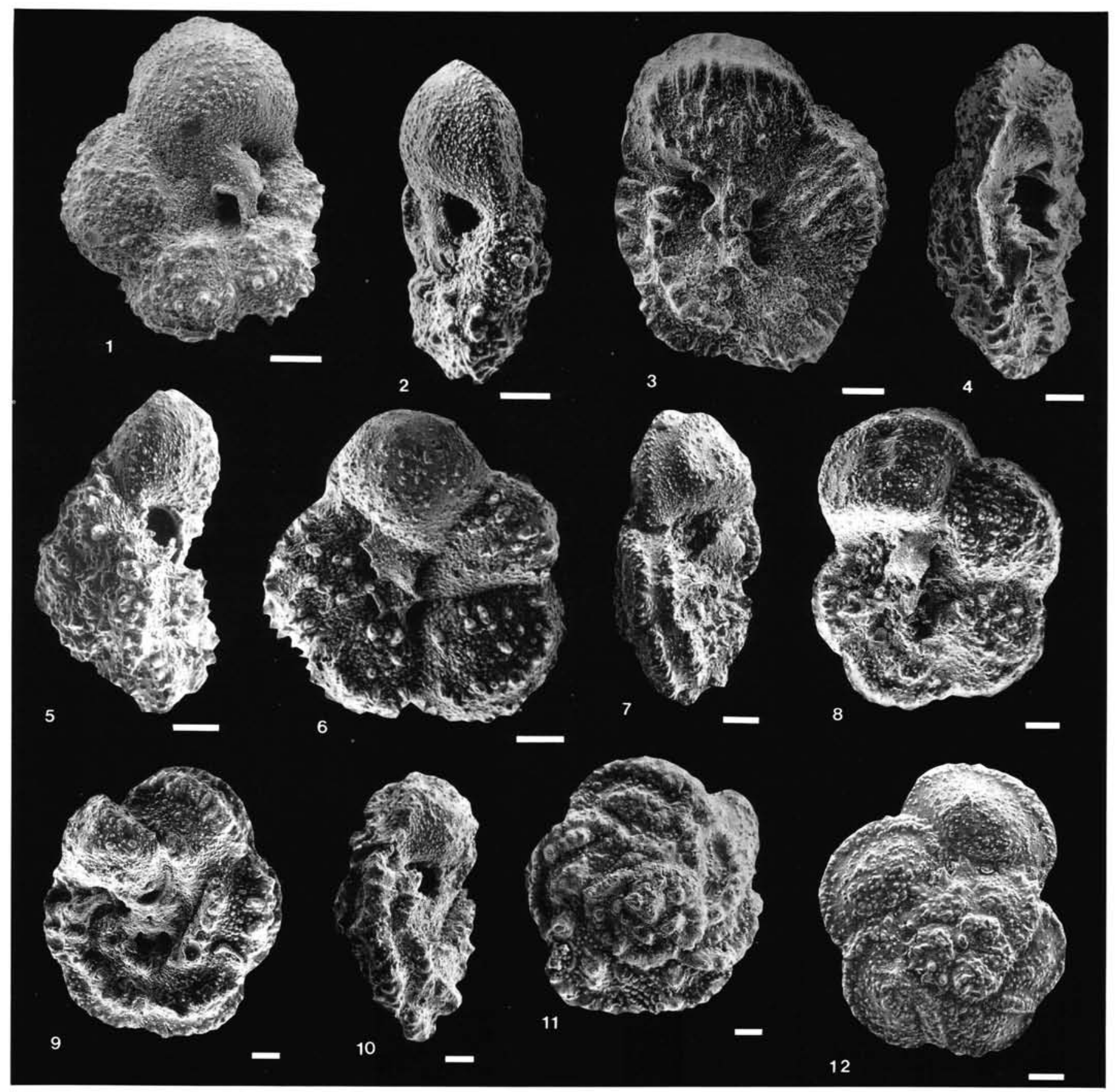

Plate 5. 1-2. Globotruncanella havanensis (Voorwijk), Sample 113-689B-28X-3, 83-87 cm. 3-4. Abathomphalus mayaroensis (Bolli), Sample 113-690C-17X-3, 119-123 cm. 5-6. Abathomphalus intermedius (Bolli), Sample 113-690C-18X-5, 46-49 cm. 7-8, 12. Globotruncana subcircumnodifer (Gandolfi), Section 113-690C-18X, CC. 9-11. Globotruncana bulloides Vogler, Sample 113-690C-18X-5, 46-49 cm. Scale bar for Figures $1-12$ is $50 \mu \mathrm{m}$. 


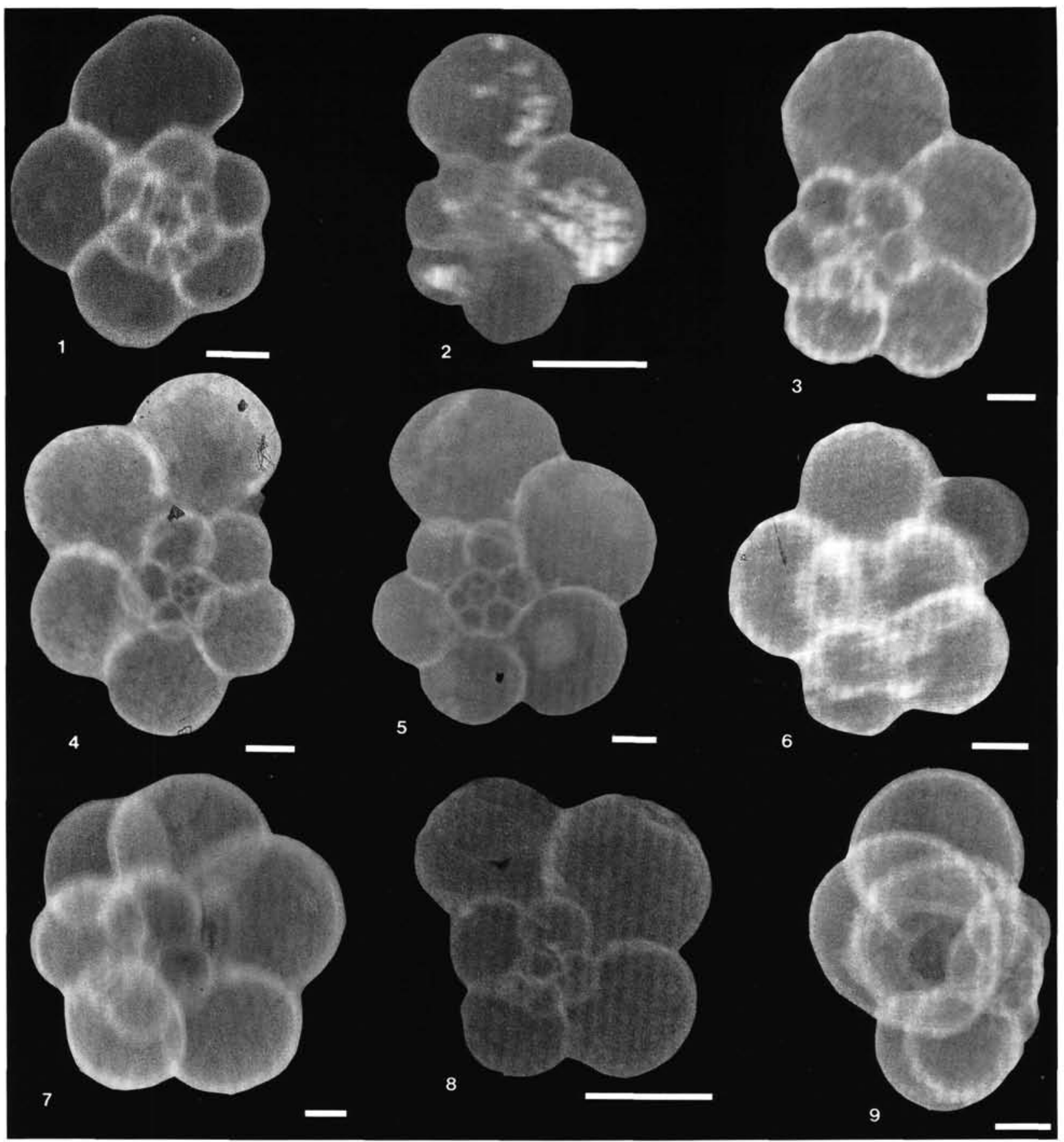

Plate 6. Microradiographs of holotypes and several other species described in this study. 1. Hedbergella holmdelensis Olsson, Sample 113-690C$21 \mathrm{X}-4,118-122 \mathrm{~cm}$. 2. Hedbergella monmouthensis (Olsson), Sample 113-690C-20X-5, 108-110 cm. 3. Rugotruncana circumnodifer (Finlay), Sample 113-690C-18X-5, 46-49 cm. 4. Hedbergella sliteri $\mathrm{n}$. sp., holotype, Sample 113-690C-18X-5, 46-49 cm. 5. Hedbergella sliteri $\mathrm{n}$. sp., from Falkland Plateau DSDP Site 327, Sample 71-327-10-3, 22-24 cm. Note the differences in ontogenetic morphology between the microradiographs of $H$. sliteri and those of $H$. holmdelensis and H. monmouthensis. 6. Archaeoglobigerina mateola n. sp., holotype, Sample 113-690C-20X-3, 119-123 $\mathrm{cm}$. 7. Archaeoglobigerina australis $\mathrm{n}$. sp., holotype, Sample 113-690C-19X-3, 119-123 cm. 8. Archaeoglobigerina australis $\mathrm{n}$. sp. Juvenile form from DSDP Site 511, Sample 71-511-23-4, 67-69 cm. 9. Archaeoglobigerina australis n. sp., Sample 113-690C-19X-6, 119-121 cm. Edge view showing ontogenetic changes in morphology. Scale bar for Figures 1-9 is $50 \mu \mathrm{m}$. 